\title{
ENTREVISTA COM MARIA LÚCIA GARCIA \\ PALLARES-BURKE ${ }^{1}$
}

Interview with Maria Lúcia Garcia Pallares-Burke

Entrevista con Maria Lúcia Garcia Pallares-Burke

CONCEDIDA A

BERNARDO BUARQUE DE HOLLANDA ${ }^{\text {** }}$

DOl: http://dx.doi.org/10.1590/s2178-149420190003000011

\footnotetext{
${ }^{1}$ Maria Lúcia Garcia Pallares-Burke é pesquisadora associada do Clas da Universidade de Cambridge.

'Escola de Clências Sociais da Fundação Getulio Vargas (CPDOC/FGV), Rio de Janeiro - RJ, Brasil.

* Bernardo Borges Buarque de Hollanda é professor-adjunto da Escola de Ciências Sociais da FGV/CPDOC.

Entrevista concedida em 23 de outubro de 2018, em Cambridge.
} 
Maria Lúcia Pallares-Burke tornou-se referência na área de pensamento social no Brasil após a publicação de dois livros alentados sobre os anos de formação de Gilberto Freyre e a influência anglo-saxã em sua obra: Um vitoriano dos trópicos (2005) e 0 triunfo do fracasso (2013). Este último, desdobramento do primeiro, fora dedicado a um de seus contemporâneos, o alemão Rüdiger Bilden, que Freyre conhecera nos Estados Unidos e que viajara ao Brasil, tendo escrito textos inéditos sobre as relações raciais no país.

Em parceria com o historiador britânico Peter Burke, Maria Lúcia foi autora também de Social Theory in the Tropics (2008), lançado originalmente em língua inglesa, traduzido e publicado no mesmo ano em português com o título Repensando os trópicos: um retrato intelectual de Gilberto Freyre. 0 livro apresenta, em visão macroscópica, a contemporaneidade das ideias freyreanas e a contribuição de um intelectual brasileiro ao público acadêmico internacional, em especial aquele não familiarizado com o controvertido sociólogo pernambucano.

Tive a oportunidade de conhecer pessoalmente a professora Maria Lúcia em setembro de 2015, por ocasião da quinta edição do Ateliê do Pensamento Social, realizado em São Paulo e promovido pelo Laboratório de Pensamento Social (Lapes), da Fundação Getulio Vargas-Centro de Pesquisa e Documentação de História Contemporânea do Brasil (FGV-CPDOC). Na condição de palestrante convidada, Maria Lúcia viajou ao Brasil para participar de uma mesa sobre os Brazilian studies, intitulada: "A circulação internacional de um 'clássico' do pensamento brasileiro — as edições de Casa-grande \& senzala em língua inglesa".

Maria Lúcia é vinculada há quase trinta anos ao Centro de Estudos Latino-Americanos (Clas), da Universidade de Cambridge. É autora de estudos sobre o educador baiano Anísio Teixeira e a escritora potiguar Nísia Floresta, entre outros. Casa-grande \& senzala (1933), que como tanta obra clássica é "mais falada do que lida", desperta um interesse especial da autora, porquanto se afigura como parte importante da biografia intelectual do Brasil. Esse trabalho, segundo a convenção interpretativa mais geral, teve por significado a redefinição da identidade nacional e a refutação do paradigma do branqueamento, tal como formulado pelos ideólogos e pelos herdeiros do racismo científico no decorrer do Oitocentos.

Se as aulas do discípulo Freyre com o mestre Boas são parte da versão canônica consagrada, a sugerir uma espécie de turning point na carreira do sociólogo, após o contato com o professor alemão radicado em Columbia, Pallares-Burke mostra como essa relação foi fortuita e aponta outras influências importantes para a compreensão mais apropriada da formação freyreana na América do Norte e na Grã-Bretanha. A título de exemplo, recorre à figura do artista britânico William Morris (1834-1896), responsável por pautar a atuação do mundo das artes, em estreita proximidade com o movimento socialista e com a crítica ao capitalismo feita desde a Grã-Bretanha oitocentista. Nessa crítica, entretanto, salta à vista certa reivindicação de um passado medieval, tão esquecido quanto oculto, no imaginário europeu, em que se projetava, não sem acento romântico, certo retorno às riquezas regionais de cada área da Europa. 
0 retorno ao Brasil do "mestre de Apipucos" encontrará nele uma liderança nordestina capaz de articular essa campanha de revigoramento tanto da "aldeia recifense" quanto da africanidade contida na revivescência do cotidiano dos engenhos açucareiros do Nordeste, célula mater em que se plasmou a identidade brasileira. Com essa chave argumentativa, Freyre encarna elementos geracionais que se despem do preconceito eugenista então dominante e despoja a historiografia do positivismo elementar, cujo ancestral oitocentista era representado pela obra do alemão Leopold von Ranke.

Após esse contato inicial com Maria Lúcia, em sua intervenção oral no Ateliê do Pensamento Social, voltei a contatá-la em 2018, dessa vez na Inglaterra, tencionando a possibilidade de um novo encontro. Propus, para tanto, uma entrevista à revista Estudos Históricos, com vistas a aprofundar aspectos do pensamento de Gilberto Freyre, motivados pela leitura dos seus livros e por sua palestra de 2015 na FGV, e também para dar a conhecer a trajetória da pesquisadora ao público mais amplo.

Agradeço à Universities United Kingdom international (UUKi), que, por meio do programa Ernest Rutherford Fellowship, outorgou-me uma bolsa de estágio pós-doutoral na Universidade de Birmingham. Foi essa agência britânica de fomento à pesquisa que deu o suporte financeiro para, entre outras atividades, a realização da presente entrevista. Sou grato à entrevistada pela generosidade de conceder-me em sua residência, numa terça-feira de outono, a gravação de mais de três horas de entrevista, feita em áudio, conforme transcrita e editada a seguir.

\section{Gostaria que você começasse falando sobre suas origens familiares.}

Primeiramente, muito obrigada, Bernardo, pois é uma honra estar sendo entrevistada por você. Quanto à minha origem familiar, vim de uma família de imigrantes, mais ou menos recentes, ambos de origem mediterrânea. Pelo lado da minha mãe, Henny, sou italiana, já que meus ancestrais eram todos italianos: meu avô, de Lucca, na Toscana; minha avó, de Laurito, nas montanhas ao norte de Salerno, a 200 quilômetros ao sul de Nápoles. Eles se conheceram numa pequena cidade do interior de São Paulo, Borborema, onde se reuniram na época muitos italianos, libaneses e sírios — os últimos eram, na verdade, chamados de "turcos", como eram todos os que chegavam do Império Otomano. Apesar de italianos, meus avós eram de famílias muito diferentes. Meu avô, de uma família orgulhosamente ateia e anarquista, e a família de Laurito, muito devota e católica praticante. Com toda a certeza, eles jamais teriam se encontrado se não tivessem se mudado para o Brasil e se conhecido nessa pequena comunidade.

Já meu pai, Francisco, era uruguaio, descendente de espanhóis que se mudaram para a América do Sul em algum momento do século XIX. Os García vinham de Andaluzia, e se conta nas memórias familiares que eram militares. Já os Pallares vinham da Catalunha. Tanto que em Barcelona o pessoal fala: "Ah, Pallares, como então não fala catalão?" É um nome 
relativamente comum lá; existe até um rio Pallares. Meu avô paterno, que não conheci, era um importante líder político do partido ruralista, o Partido de Los Blancos. Do lado dos Pallares, meu bisavô era um médico de origem catalã. Enfim, bem diferentes os García dos Pallares. Os segundos eram mais calmos, enquanto os primeiros eram do tipo briguento e apaixonado.

\section{Conte um pouco sobre sua formação escolar.}

Nasci na cidade de São Paulo, e, até entrar na Universidade de São Paulo (USP), eu só havia estudado em uma escola brasileira, localizada na bela Praça da República, no centro de São Paulo. Era o Instituto de Educação Caetano de Campos, essa escola-modelo da qual a gente se orgulhava muito, sempre sendo lembrada pelos professores de sua história, iniciada em 1894, como um monumento republicano, tanto na sua construção belíssima quanto nos seus ideais. Entrei ali com três anos, mais cedo do que a maior parte das crianças, porque minha mãe era professora da escola. Ela tinha, na verdade, iniciado a brilhante carreira — acho que a carreira mais importante num país é a de professora primária - com dezenove anos, dando aula numa escola rural do interior paulista, perto de Borborema, antes de ser transferida para a Escola Rural de Brejo Alegre, numa região distante, no noroeste paulista, onde viveu praticamente imersa numa comunidade japonesa por alguns anos durante a Segunda Guerra.

\section{E qual era a profissão de seu pai?}

Meu pai, apesar de gostar muito de estudar, não fez universidade. Teve uma vida familiar muito complicada. Perdeu a mãe com oito anos, teve de se mudar para a capital com o pai para longe da fazenda, perto de Durazno, que adorava, e ele logo se casou com Carlota, uma beldade de Montevidéu. Com desesseis ou dezoito anos, fugiu de casa e veio parar no Brasil. Então, a vida foi difícil. Por décadas, teve um emprego numa indústria francesa, na qual fez uma bela carreira, mas o sonho dele era ser fazendeiro ganadero, seguindo a tradição familiar. Adorava fazenda, terra, cavalos, gado. Chegou a ter uma fazenda de gado certa vez, com o irmão mais velho radicado no Brasil, que acabou não dando certo. Mas meu pai era também um grande apreciador de história. Lia muito, adorava conversar e comentar os livros que lia com um entusiasmo contagiante. Era, na verdade, apaixonado especialmente pela história da América Latina e pelas histórias de grandes impérios antigos, sobretudo o da Babilônia. Admirava figuras guerreiras, exemplares pela sua bravura, e os nomes que sempre apareciam em suas conversas eram bem distantes um do outro, no tempo e no espaço: Artigas (1764-1850), o herói nacional uruguaio que lutou bravamente pela independência do país e pelos ideais republicanos, e Nabucodonosor (634-562 a.C.), o grande estrategista que derrotou assírios e egípcios, transformando a Babilônia numa potência militar e artística. Como meu pai era grande leitor da Bíblia - a qual lia mais pelo interesse histórico, literário e cultural, de modo geral, do que por interesse religioso propriamente dito —, foi dela, acho, que veio a paixão 
pela história da Babilônia. Ele tinha uma visão épica de história, e não por acaso gostava tanto do poema Martín Fierro, que sabia quase todo de cor.

\section{Talvez pelas origens familiares ele tivesse essa visão...}

Sim, provavelmente. Mas voltando à minha formação, estudei dos três aos dezessete anos na escola Caetano de Campos. Com dezessete, no segundo ano do colegial, saí porque ganhei uma bolsa de estudos nos Estados Unidos. Na época não era uma coisa tão comum. A bolsa era para eu passar um ano com uma família norte-americana e cursar uma High School. Isso fazia parte de um programa chamado American Field Service International Scholarship (AFS), uma organização não governamental fundada logo após o fim da Segunda Guerra Mundial com o objetivo de ajudar a "criar um mundo mais justo e pacífico". Tinha um exame competitivo, e naquele ano houve mil e tantos candidatos. Fui uma das duzentas pessoas do Brasil agraciadas com essa bolsa.

\section{Você estudava inglês na escola ou também estudava fora?}

Eu frequentava o curso de inglês da União Cultural Brasil-Estados Unidos. Achava, portanto, que sabia inglês o suficiente e que entenderia as aulas e o inglês falado sem dificuldade, pois era boa aluna e minha gramática era vista como "quase perfeita". Doce ilusão. Passei alguns meses boiando nas aulas, apesar de ter me transformado logo em corretora de gramática dos trabalhos escritos de meus colegas. Ironicamente, a aula em que o ambiente era mais soporífico era a de história norte-americana, e cheguei a cair no sono mais de uma vez. Durante uns dois meses, a voz de mister Oleaceski soava como música para meus ouvidos.

\section{Em que cidade nos Estados Unidos?}

Era uma cidade pequena, New Castle, na Pensilvânia, não muito longe da fronteira de Ohio e a uma hora de Pittsburgh. Essa penso ter sido a experiência mais marcante da minha vida. Pela primeira vez eu saía do Brasil e me via num território nada familiar, totalmente estranho, que desafiou muito meu modo de pensar e de me comportar, em meados dos anos 1960.

\section{Você morou com uma família norte-americana?}

Sim. Viver com uma família estrangeira, num país estrangeiro, estudar numa escola estrangeira quando eu tinha dezessete anos, foi definitivamente uma life changing experience, uma experiência transformadora, memorável, talvez a mais importante para a pessoa que me tornei. Eu queria muito sair do Brasil por um tempo, queria ter outra experiência de vida, e na União Cultural Brasil-Estados Unidos fiquei sabendo desse programa de intercâmbio muito conceitua- 
do e famoso. Nesse período, frequentei o último ano do High School, e ali vivi uma experiência total, já que a vida do adolescente norte-americano se passa ao redor da escola. Aprendi muito, e não tanto sobre disciplinas específicas, mas a apreciar as diferenças culturais, pois não convivi somente com os norte-americanos. O programa do AFS tinha um ethos muito internacional e, como queria trabalhar em prol da solidariedade humana, dava muita importância ao convívio dos bolsistas com pessoas de diferentes origens. Criavam, assim, muitas oportunidades para, ao longo desse ano, nos encontramos com outros bolsistas do mundo todo.

Foi assim que convivi muito com argentinos, chilenos, colombianos, mas também com jovens do Marrocos, da Índia, da Alemanha, da Islândia, da Holanda, do Egito etc. Fazia parte do programa darmos palestras sobre nosso país para os norte-americanos - em outras escolas e em associações variadas, como a 19th Century Society, de New Castle, por exemplo, cujos membros tinham de ser nascidos naquele século. Nessas ocasiões, encontrávamos outros bolsistas que viviam na região. Então, acho que o resultado disso, para mim, foi aprender a apreciar as diferenças culturais, mas também — e talvez isto seja o mais importante - a me conscientizar quão semelhantes os seres humanos são, apesar de todas as diferenças. Estive recentemente em New Castle revendo meus amigos, numa comemoração de minha turma da Neshannock High School: cinquenta anos de formatura. Uma das boas coisas do Facebook é tornar encontros desse tipo possíveis, porque foi por meio dessa rede social que me descobriram.

\section{Eu ia justamente perguntar se você manteve contato com as pessoas que conheceu lá.}

Com a família, mantive sempre, mas não com a grande maioria de meus colegas. Fui a convidada de honra do grupo nesse evento. Nessa ocasião, fui visitar a escola, que parece não ter mudado em nada desde sua fundação, poucos anos antes de lá chegar. É muito bem equipada, bem cuidada, com grande espaço aberto. De repente, quando eu estava com uma amiga na recepção, chegou um senhor e disse: "Maria, how are you? Do you remember me?" Eu não lembrava, mas ele era mr. Bleggi, que havia sido meu professor de inglês. Além disso, também era treinador de basquete, e continuava fazendo isso depois de aposentado, por isso ainda estava por lá. Ele me contou uma história engraçada, da qual não me recordava. Ele me dera a nota máxima, um A, e eu, surpresa, cheguei para ele e perguntei: "Como o senhor me dá um $A$ ? Meu inglês ainda está tão ruim!"

Ele explicou que nunca se esquecera de minha atitude, que contrastava, segundo ele, com a dos estudantes anteriores do AFS, que eram muito "arrogantes". Eu não havia conhecido nenhum antigo estudante AFS daquela escola, pois eu era a única naquele ano. Meus colegas AFS em outras escolas não eram diferentes de mim. Enfim, mr. Bleggi me dera um A não só porque, segundo ele, meu inglês oral não era tão ruim e o escrito era bom, mas porque eu era diferente dos alunos anteriores. 


\section{Foi essa sua experiência no exterior um ano antes do vestibular?}

Quando voltei para o Brasil, queria entrar na faculdade imediatamente. Naquele ano de High School, eu não havia estudado as matérias que me permitiriam entrar em cursos que cogitei, como direito na São Francisco. Resolvi prestar vestibular na USP, nas áreas em que meu preparo bastava, e sem muita reflexão escolhi o curso de pedagogia na Faculdade de Filosofia, Ciências e Letras.

\section{Isso era fim dos anos 1960 ? Uma conjuntura bastante delicada.}

Sim, e o curso foi muito além das minhas expectativas. É claro que havia matérias que não me interessavam, como administração escolar. Mas foi além das minhas expectativas pelo nível dos professores que tive. Alguns deles, especialmente os que haviam se licenciado em filosofia pela Faculdade de Filosofia da USP, eram hors concurs, inesquecíveis, realmente inesquecíveis pela cultura e pela sabedoria. 0 clima era tenso, como pode imaginar. Muitas vezes, os professores chegavam visivelmente transtornados por terem notícia de algum colega que fora preso. Entre nós, alunas, também havia muita tensão. Tivemos algumas colegas que desapareceram, e suas fotos eram fixadas em paredes de supermercado na lista de "procura-se". Por outro lado, entre os intelectuais da época, havia figuras notoriamente contrárias a ler obras de Gilberto Freyre, por exemplo, graças ao apoio ao golpe militar de 1964.

\section{Sua mãe era professora. Você já tinha interesse pela área de educação?}

Sim. Isso deve ter pesado muito, mesmo que na época eu não tivesse me dado conta. Em especial, preciso mencionar um professor que conheci na graduação. Dediquei meu livro de entrevistas, As muitas faces da história, a ele: professor João Eduardo Rodrigues Villalobos, filósofo e professor de filosofia da educação da USP. Foi uma figura inesquecível não só para mim, como para muitos dos meus colegas. Eu diria que as qualidades que porventura houver no meu trabalho se devem a ele, sem nenhuma dúvida. Impressionava sua inteligência, briIhantismo, cultura, perspicácia, amplos horizontes, e também sua exigência e intransigência quando percebia que não pensávamos com a própria cabeça. A gente morria de medo dele, mas, ao mesmo tempo, ele nos cativava pelo brilho, pelas ideias que expunha, por suas provocações e pelas dúvidas que levantava sobre nossas certezas apressadas.

Villalobos não era só professor de história e filosofia da educação, mas também um militante da educação. Foi um dos líderes na campanha pela defesa da escola pública no fim dos anos 1950 e, especialmente, no ano 1960, um movimento que lutava por uma escola democrática, laica e gratuita - movimento que foi abraçado por várias figuras da envergadura de Anísio Teixeira, Darcy Ribeiro e Roque Spencer Maciel de Barros, este também nosso professor de história e filosofia da educação. Nessa época, Villalobos já escrevia para O Estado 
de S. Paulo, como editorialista de educação e colaborador, com matéria assinada, nesse jornal e também no Jornal da Tarde.

Uma das coisas mais difíceis que já escrevi na vida — acho que a coisa mais difícil — foi um verbete sobre João Eduardo Rodrigues Villalobos no Dicionário dos educadores do Brasil. Difícil porque, dentro dos limites de um verbete, queria ser capaz de expor todo o seu valor como professor, militante e pensador. Villalobos deixou uma obra escrita que revela seus variados interesses, desde a campanha pela escola pública, sobre a qual escreveu um livro denso e provocativo, Diretrizes e bases da educação: ensino e liberdade (1969), até o pensamento do filósofo inglês George Berkeley, sobre o qual escreveu um belíssimo trabalho.

\section{Nessa época o curso era na Maria Antônia?}

Não, já era na USP, da Cidade Universitária, no Butantã. Nunca estudei na Maria Antônia. Meus professores, sim, haviam todos estudado na Maria Antônia. Tenho certeza de que João Eduardo Villalobos marcou muitos trabalhos que saíram da Faculdade de Educação. Meus dois primeiros livros - um sobre Anísio Teixeira, fruto do meu mestrado, e outro sobre o lluminismo europeu, do meu doutorado — têm a marca indelével de sua orientação estimulante, amiga e extremamente crítica.

\section{Então, sua pós-graduação, seu mestrado e seu doutorado foram feitos na USP com 0 próprio.}

É, mas há um detalhe. Resolvi fazer o doutorado sobre o Spectator, jornal inglês do século XVIII. Como o Villalobos era também interessado em educação no sentido amplo, fora dos quadros propriamente formais e escolares, deu-me todo o apoio quando resolvi escrever um doutorado sobre o papel educativo de um diário do lluminismo europeu — tema que não era muito convencional na Faculdade de Educação.

\section{Que você descobriu de que maneira?}

Vou contar. Hoje em dia acho que é diferente, mas naquele tempo a gente entrava para o curso de doutorado sem ter de saber sobre o que escreveria. Eu já havia feito muitas matérias necessárias que o curso de doutorado exigia e permanecia indecisa quanto à tese que deveria produzir. Cheguei a pensar em continuar a estudar não o pensamento e a ação de Anísio Teixeira, mas as forças contrárias que ele teve de enfrentar durante sua carreira de educador: o grupo católico que fazia ferrenha oposição a ele, tachando-o de comunista. Comecei a fazer a pesquisa sobre esse tema, mas, diferentemente do que acontecera quando eu estudava a trajetória intelectual de Anísio Teixeira, no seu período formativo, o tema não me apaixonava. 


\section{E isso era em que momento?}

Era começo dos anos 1980, quando o doutorado começou. Eu também não sentia muito entusiasmo por parte dele [orientador]. Ele era normalmente "entusiasmador", mas deve ter percebido que, sem uma dose de paixão pelo tema, eu não iria ser bem-sucedida. Penso que é necessário certa paixão para fazer um bom trabalho. Nesse meio-tempo, chegou a notícia de que a Faculdade de Educação recebera recentemente, como doação, a biblioteca do Instituto de Educação Caetano de Campos. Foi após o instituto ter deixado de ser aquilo que era, ter se desligado de sua história de escola-modelo e mudado de prédio em 1978.

Senti que parte da minha história chegara perto de mim. Eu era grande frequentadora da biblioteca da Caetano e havia passado muitas e muitas horas naquela sala ao longo de minha vida de estudante. Fui até a biblioteca da Feusp e procurei os livros doados. Ainda havia muita coisa em caixote, mas nas estantes já haviam colocado, sem muita ordem, parte do acervo. Comecei, então, a passar os olhos para ver o que estava lá e deparei com oito volumes um pouco maiores do que livros de bolso. Eram livros bonitos, encadernados em couro, com 0 título em letras douradas, se não me falha a memória, publicados em 1757, em Londres: The Spectator. Eu não tinha noção do que se tratava, nunca ouvira falar em The Spectator nem no periódico semanal com o mesmo título, mas do século XIX, ainda hoje existente, que Karl Marx tanto criticara como um jornal "filisteu".

Peguei o primeiro volume e o abri de maneira aleatória - literalmente foi isso, o que mostra a força da serendipity e o que pode acontecer numa busca sem planos - numa página. Era o número 11 do jornal, publicado em 13 de março de 1711. Tratava-se de uma conversa em que um indivíduo falava de forma muito desrespeitosa sobre as mulheres, descrevendo-as como seres intelectual e moralmente inferiores, diante de Arietta, uma mulher sábia. A resposta de Arietta foi mais ou menos a seguinte: "Deixe-me lhe contar uma história, e lembre-se de que muito do que se fala contra as mulheres é porque a história é escrita por homens." Minha reação foi: "O quê? Parece tão moderno isso!" Arietta, então, conta uma história marcante, que já fora contada e escrita no século XVII, sobre o encontro de uma índia com um inglês em dificuldade, um comerciante.

A história é a seguinte: a índia Yarico salva o comerciante Inkle dos índios que o perseguiam, escondendo-o num recanto da floresta. Ela cuida dele, e os dois vivem como amantes por vários meses, chegando até a aprender a língua um do outro. Um dia, instruído por ele, Yarico atrai a atenção de um navio levada pelas promessas que Inkle the fizera de uma vida de fausto e paz se ela o acompanhasse à Inglaterra. 0 navio se dirigia a Barbados. Ao chegar lá, Inkle vende Yarico como escrava, não se compadecendo ao saber que ela estava grávida de um filho seu. Essa informação só serviu para ele aumentar o preço pedido por sua "mer- 
cadoria". Li essa história e fiquei surpresa por estar sendo publicada e discutida em 1711. Foi então que, encantada com a amostra que vira, comecei a me interessar por saber mais sobre o Spectator, periódico que, de fato, dá espaço para um feminismo incipiente.

Fiz um primeiro trabalho sobre o Spectator para o curso sobre Rousseau - um dos meus grandes interesses à época — ministrado pelo professor Salinas [Luiz Roberto] na filosofia da USP. Tínhamos de fazer um trabalho de fim de curso, e o Salinas sugeriu que eu escrevesse sobre algum aspecto do Emílio de Rousseau. Eu já havia lido Emílio muitas vezes, achava-o um belíssimo tratado de educação, mas, tendo descoberto o Spectator recentemente, Ihe disse que escreveria alguma coisa sobre esse jornal iluminista, o que quer que eu conseguisse em pouco tempo. Até porque havia descoberto que Jean-Jacques Rousseau fora um grande leitor do The Spectator, obra que ele cita em As confissões e recomenda como leitura de Emílio e Sophie em Emílio. Então, logo após ter feito esse primeiro trabalho para o Salinas, resolvi fazer meu doutorado sobre o Spectator com todo o apoio do Villalobos. Foi para isso que, tendo recebido uma bolsa do CNPq, vim fazer pesquisa em Londres.

\section{Já existia bolsa-sanduíche naquela época?}

Não. Eu poderia ter ficado na Inglaterra por cinco anos, mas não fiquei por questões familiares. Àquela altura eu já tinha quatro filhos pequenos, e também por motivos profissionais não podia ficar aqui por tanto tempo. Fiquei um ano em Londres, orientada pelo professor Peter Gordon, historiador do Instituto de Educação da Universidade de Londres, ao qual me filiei. Tive, pois, dois orientadores: professor Peter Gordon, da Universidade de Londres, e professor João Villalobos, da USP. Mas defendi o doutorado na USP.

\section{Então, depois do ano escolar nos Estados Unidos, foi sua primeira experiência acadê- mica fora.}

Sim, foi a primeira experiência acadêmica fora, em meados dos anos 1980. Defendi meu doutorado em 1986.

\section{Imagino o peso que tinha uma tese de doutorado nos anos 1980 com todo o rito da banca.}

É, a banca foi excepcional. Eu tinha uma imensa admiração pelo Gérard Lebrun, da filosofia, e foi a maior honra para mim ele ter aceitado ser um dos examinadores. Na banca também estavam o Oliveiros $\mathrm{S}$. Ferreira, que, além de ser professor de ciência política, era um renomado jornalista do Estadão, jornal que dirigiu; Nicolas Boer, ex-padre e deputado húngaro, que fez parte da resistência aos nazistas e fugiu da Hungria em 1949, quando a perseguição aos católicos se acirrou — chegou ao Brasil em 1950, onde se estabeleceu como sociólogo e 
jornalista, tendo sido também editorialista do Estadão, no qual escrevia sobre política internacional. Além do Villalobos, o quinto membro da banca foi Peter Burke, que não era doutor.

\section{Mas deveria ter o título de doutor para estar na banca.}

Voltei para a Inglaterra por uns meses quando já estava com o trabalho avançado, porque alguma coisa faltava na minha pesquisa. Foi então que conheci o Peter [Burke]. Meu chefe de departamento na USP me dera a incumbência de convidar um acadêmico britânico que tivesse interesse em passar uns meses no Brasil para dar aula no curso de pós-graduação da Faculdade de Educação. "Você está indo para lá passar alguns meses, procure ver se consegue alguém que tenha interesse em vir para cá, porque estamos querendo promover a vinda de professores estrangeiros." Convidei primeiramente o Keith Thomas, que recusou, mas me sugeriu que procurasse seus ex-alunos, Peter Burke e Alan MacFarlane.

Foi assim que tudo começou. Eu acabara de conhecer o Peter profissionalmente, e o Villalobos, ao saber de sua vinda da Inglaterra, me disse: "Bom, vou escrever a ele, já que ele vai estar aqui, perguntando se não gostaria de participar da banca." Então, ele também participou da banca, apesar de não ter o título de doutor. Não sei como eles resolveram essa questão burocrática àquela altura. Anos depois, quando foi convidado do Instituto de Estudos Avançados, criou-se um impasse na hora de pagarem seu salário, pois nunca haviam ouvido falar, ao que parece, de pessoas renomadas, com vários livros de peso publicados, sem o título de doutor.

\section{Era o mesmo procedimento atual, de dois avaliadores internos e dois externos?}

Sim, isso mesmo. Enfim, adorei ter escrito esse trabalho sobre o Spectator, apaixonei-me pelo tema e fiquei extremamente gratificada pelo nível da arguição que tive na defesa de tese.

\section{Tanto que você publica em livro depois.}

Sim, um livro sobre o papel formativo do jornal The Spectator, que foi um fenômeno jornalístico e educacional, em sentido amplo. Um fenômeno não só durante o lluminismo, já que sua repercussão ultrapassou não só as fronteiras inglesas, como também o século XVIII, tendo chegado ao Brasil e à América Latina no século seguinte. Muito mais naquela época do que agora, a educação não se confundia com a escola nem os educadores se confundiam com mestres de profissão. Muito se escrevia no século XVIII sobre as várias maneiras como as pessoas são educadas: pelo que elas leem, pelo teatro que frequentam, pelo ambiente em que vivem etc. Como disse o filósofo Helvetius, "cada um tem como preceptor a forma de governo sob a qual vive, seus amigos, suas mestras, as pessoas que o cercam, suas leituras e, enfim, o acaso". Efetivamente, jornalistas filósofos, jornalistas, teatrólogos, romancistas, pintores e 
até músicos tendiam a se considerar educadores devotados à tarefa de ilustrar o público, e o faziam sem nenhuma indecisão e sem nenhuma preocupação em parecerem doutrinadores.

O jornal Spectator faz parte desse quadro e foi inovador também porque era um diário, mas enquanto era publicado diariamente já começaram a publicá-lo sob forma de livro. Enfim, era um jornal que virava livro ao mesmo tempo que suas folhas avulsas eram vendidas. E também foi quase imediatamente traduzido. Logo em 1711, já estava sendo traduzido na Holanda para o francês e depois para o francês na própria França. Muitos dos jornalistas logo quiseram imitá-lo, e isso deixavam bem claro, sem sofrerem qualquer "angústia da imitação". Surgiram, assim, inúmeros Spectators, primeiramente na Europa e depois nas Américas. E quando digo "inúmeros" não é por força de expressão. Na Holanda, por exemplo, houve setenta seguidores publicados em holandês e francês. Na França, umas cem imitações do Spectator foram publicadas antes da Revolução Francesa. Na Alemanha, em 1739, já se dizia que os descendentes do Spectator eram tantos que era impossível contá-los.

\section{Então, eram esses oito volumes que você pesquisou na biblioteca e que depois pôde aprofundar nas outras fontes pesquisadas na Inglaterra?}

É, fiz pesquisa na Inglaterra durante um ano para meu doutorado, mas voltei em 1988, para ampliar a pesquisa e transformar a tese num livro que publiquei anos depois. Nem lembro quando que ele saiu.

\section{Em 1995, o The Spectator, o teatro das luzes.}

Sim, isso mesmo. The Spectator, o teatro das luzes: diálogo e imprensa no século XVIII. Antes de publicar esse livro eu queria ampliar meu doutorado. Eu sabia sobre os seguidores europeus de Addison e Steele, os autores do Spectator, mas não os tinha pesquisado em profundidade. Então, vim para cá e trabalhei na Inglaterra, na França, e depois fomos para Berlim, onde estivemos um ano, de 1989 a 1990, ligados ao Instituto de Estudos Avançados de lá. Trabalhava diariamente na Staatsbibliothek, que ficava ao lado do muro de Berlim, e foi então que assistimos estupefatos à queda do muro de Berlim. Meu alemão falado era muito ruim, mas bom o suficiente para ler muitos seguidores alemães do Spectator, o que fiz não só em Berlim, mas também em Halle. Também estive na França, onde os spectateurs floresceram durante todo o século XVIII e parte do XIX. Refiro-me a isso no último capítulo desse livro, todo ele fruto dessa pesquisa posterior.

\section{Foi uma bolsa de pós-doutorado financiada pelo governo brasileiro ou já era daqui?}

Não, uma parte pequena pela Fapesp e uma parte maior pelo British Council. 


\section{Você ficou vinculada à Universidade de Cambridge no pós-doutorado?}

Sim, no pós-doutorado, fiquei vinculada ao departamento de história da Universidade Cambridge e ao Darwin College, e depois me vinculei ao Centre of Latin American Studies, da qual sou research associate há muito tempo.

\section{Nessa sequência, você acaba por se radicar em Cambridge?}

É aí que entra o lado mais pessoal. Eu havia conhecido o Peter em 1985, rapidamente, quando fiz o convite pra ele ir para o Brasil. Ele aceitou. Eu não sabia que ele adorava viajar. Na verdade, fiz alguns outros convites. Cheguei a ele por intermédio do Keith Thomas, um grande historiador que fora seu orientador. Um amigo organizou esse encontro com o Keith Thomas em Oxford. Ele me convidou para almoçar no belíssimo Corpus Christi College, do qual era o president (equivalente a reitor). Fiz o convite e ele me fez uma só pergunta: "São Paulo, quantos milhões de habitantes tem?" Acho que eram 12 milhões na época, e ele disse: "Not for me, not for me. Mas tenho dois alunos que gostam de ter experiência fora daqui e não se importam com o tamanho da cidade."

Ele escreveu dois nomes num papel: Peter Burke e Alan Macfarlane, nessa ordem. Alan é antropólogo, amigo nosso. Escrevi inicialmente para o primeiro da lista, dizendo qual era a intenção do encontro, pois não podia escrever para os dois, já que só podia convidar um. Encontrei com o Peter aqui em Cambridge, no Emmanuel College, e ele aceitou imediatamente o convite. No ano seguinte, 1986, ele foi para o Brasil, ficou lá alguns meses e deu um curso de pós-graduação na Faculdade de Educação muito concorrido, que atraiu gente de muitas outras faculdades. Então, quando vim para cá, no fim dos anos 1980, já estávamos juntos.

\section{A partir do pós-doutorado, você decidiu se radicar.}

Fiquei mais ou menos entre São Paulo e Cambridge. Eu ia muito para o Brasil, dava alguns cursos, voltava... De fato, eu não sabia muito bem o que fazer. No fim, afastei-me da USP, mas ainda fiz a minha livre-docência com uma coleção de ensaios inspirados no meu interesse pelo jornalismo, quase todos eles - não todos, porque o da Nísia Floresta não é bem sobre seu jornalismo. Mas todos eles giravam ao redor da questão da recepção e da circulação das ideias, o tema mais amplo que sempre me fascinou.

\section{Então também já há essa aproximação com a história, com a historiografia, talvez até pelo próprio contato com o Peter Burke, que era historiador, e do seu interesse por história das ideias, que já vinha com o lluminismo. Tudo isso se acentua.}

Sim, tem razão, isso se acentua muito com meu convívio com o Peter, que enfatizava nos seus estudos a importância das chamadas "obras menores" de uma época para reconstruir a 
mentalidade dominante, mas também a mentalidade subalterna revelada especialmente pela cultura popular. Estudando o lluminismo por meio de suas chamadas "obras menores", como os periódicos culturais, minha visão da história intelectual desse período histórico se ampliou substancialmente. Entre os periódicos iluministas que estudei, houve um, Le Journal Étranger, que particularmente me fascinou. Não sei bem como o conheci. Ah, foi por intermédio do Rousseau, que esteve inicialmente envolvido nesse projeto! Ao contrário do Spectator, era um periódico menos dirigido a uma crítica dos costumes e mais a uma clara defesa do "outro", do étranger, como objeto de admiração e imitação.

Publiquei um artigo sobre esse assunto primeiro em inglês, antes de publicá-lo em português na minha livre-docência, já que o material apresentado poderia ter sido publicado antes. Le Journal Étranger (1754-62) é um jornal formativo muito inovador do século XVIII. Era uma publicação periódica, não diária, mas claramente educacional. Seu lema poderia ser resumido no seguinte: "Imitemos o que é bom." 0 respeito ao outro, a admiração pelo outro, de onde quer que ele seja, abre a possibilidade de aprendermos com o outro, com outras culturas, defendia o periódico. Era um belíssimo trabalho, que ainda tem muito a ensinar ao mundo contemporâneo. Em suma, meu interesse pelo jornalismo se aprofundou após meu encontro com o Spectator na Faculdade de Educação.

É claro que eu estava muito informada também pela ideia ampla de educação que o professor Villalobos tinha e que ele nos ensinara a admirar. Foi com ele que fizemos, ao longo de um bom tempo, uma leitura vagarosa de um livro da maior importância, o Paideia, do Werner Jaeger, obra que mostra que a grandeza da antiga civilização grega está na importância que eles davam à educação, mas não a educação no sentido estreito, técnico, pedagógico, e sim no sentido de formação, da virtude e da cidadania. Enfim, as aulas do Villalobos eram muito informadas por essa visão ampla da educação.

\section{Baita livro, de cultura humanística ampla e profunda!}

Isso, exatamente. Então, eu estava interessada em educação, num sentido amplo, que podia ser rastreada em muitos lugares, e não apenas em salas de aula.

\section{E a Nísia Floresta, que é uma personagem feminina que também a cativa?}

A Nísia Floresta... Bem, nos anos 1990, eu estava muito ligada ao jornalismo, que era um meio privilegiado em que as ideias circulavam. Ao circularem, elas eram apropriadas por outros, transformadas, adaptadas a novos contextos. Então, eu estava interessada no fenômeno da circulação das ideias e como elas ocorriam. Esse era o grande tema. Resolvi fazer um trabalho sobre a famosa tradução de Nísia Floresta, de 1832, do livro da feminista britânica Mary Wollstonecraft, A vindication of the rights of woman. Nísia dizia que fizera uma tradução 
livre do texto inglês, então pensei: "Vou fazer um trabalho vendo como a Nísia adaptou para o contexto brasileiro um texto estrangeiro, o que ela fez, enfim, com o texto original da Mary Wollstonecraft."

O mero fato de ela ter feito uma tradução àquela época não deixava de ser surpreendente. Tratava-se de uma jovem que nascera no Rio Grande do Norte, mudara-se para Pernambuco e, de repente, traduziu um tratado feminista escrito no contexto da Revolução Francesa e dirigido a um dos seus líderes. Eu queria ver como o texto da Mary Wollstonecraft fora adaptado para o público brasileiro. Alguns anos antes, em 1989, havia sido republicada a tradução de 1832 com uma introdução de uma estudiosa de Nísia Floresta, Constância Lima Duarte. 0 texto de Nísia era facilmente acessível, e eu tinha comigo o da Mary Wollstonecraft, sobre o qual eu já havia trabalhado anteriormente, quando estudara o Spectator e o lluminismo europeu.

Comecei a ler o livro da Nísia Floresta e fiquei profundamente intrigada: "Isso não é tradução", pensei, "nem livre nem literal. Isso não é a tradução da Mary Wollstonecraft". Questões centrais do texto da Mary Wollstonecraft não estavam no livro. A figura do Rousseau, essencial para o combate em que a autora britânica estava envolvida, também não aparecia em nenhum momento no texto de Nísia. Confesso que fiquei arrepiada: "Isso não é a tradução. E se ela não traduziu Wollstonecraft, o que, então, fez?" Comecei a ficar obcecada — fico obcecada com as coisas. Li reli e, de repente, me veio uma pequena luz, uma sensação de déjà vu: "Já vi isso, essas palavras, em algum lugar. Essa colocação não me é estranha."

Foi quando tive um estalo. Bastava confirmar minha suspeita. Minha filha estava aqui na Inglaterra e eu estava lá no Brasil dando aula. Entrei em contato com ela e disse: "Renata, é urgente. Procure o livro Woman not Inferior to Man, de Sophie, a person of quality. Tenho uma cópia e deve estar em tal e tal lugar da casa. Se não achar, vá à biblioteca central da universidade, tire outra cópia e me mande. 0 texto, um tratado feminista bastante radical, era de 1739, muito anterior ao de Mary Wollstonecraft. Quando chegou o livro, confirmei que Nísia fizera uma tradução ipsis litteris do tratado feminista de Sophie, obviamente um pseudônimo do autor ou autora, cuja identidade real jamais foi descoberta.

\section{Incrível...}

Incrível mesmo! Enfim, não havia dúvida alguma quanto a esse fato. Colocando os dois textos lado a lado, era evidente que o texto de Nísia era uma tradução literal do texto de 1739. Um texto que, por sua vez, fora inspirado por um tratado feminista cartesiano do século XVII, De l'égalité des deux sexes, de autoria de um padre chamado François Poulain de La Barre e que, na verdade, se apropriava de várias partes deste. "E o que faço com isso?", pensei. "Durante mais de 150 anos, acreditou-se que Nísia fizera uma coisa que ela não fez; isso é assunto de jornal." Eu não conhecia ninguém da Folha à época, mas entrei em contato com o editor do Caderno Mais, Alcino Leite Neto, que foi muito receptivo. 
Expliquei o caso e the disse: "Gostaria de publicar no jornal uma versão pequena de um trabalho maior que estou escrevendo" - e que na verdade publiquei logo depois, em 1995, no livro Nísia Floresta: 0 carapuceiro e outros ensaios de tradução cultural. Ele aceitou e publicou o artigo em setembro de 1995, revelando ao público o fato de que Nísia traduzira um tratado mais radicalmente feminista do que o escrito por Mary Wollstonecraft. "Há o fato e há minha interpretação", expliquei ao Alcino. "Minha interpretação está aberta a mil críticas, questionamentos, mas o fato é inelutável". Nesse momento apareceu um lado triste do mundo acadêmico, do mundo intelectual: a reação foi violenta no Rio Grande do Norte. o Conselho Estadual de Cultura do Rio Grande do Norte escreveu para a Folha, e o Alcino me perguntou se eu queria responder. Respaldados pela especialista em Nísia, Constância Lima Duarte, eles negaram o fato e consideraram o texto ofensivo "à memória da pioneira do feminismo no Brasil". Quando vi o tipo de reação, puramente emocional e sem argumento, disse ao Alcino: "Não existe diálogo possível quando se desce a esse nível de anti-intelectualismo e de um bairrismo triste, muito triste. Não, não vou responder". 0 Mais publicou um texto se referindo à reação dessas pessoas, e, desde então, pelo que sei, sou tida, em alguns círculos do Rio Grande do Norte, como a pessoa que manchou a reputação de Nísia Floresta, que a denegriu.

$\mathrm{Na}$ verdade, tenho certeza de que minha descoberta fez de Nísia uma pessoa mais interessante, mais radical e mais destemida do que se pensara durante mais de 150 anos. Desde então, no entanto, prevalece no Brasil, lamentavelmente, um silêncio sobre a verdadeira realização de Nísia nos meios que tratam do feminismo brasileiro, ou um descrédito de minha descoberta. Fora do Brasil, no entanto, há intelectuais que levantam essa questão: "Por que essa conspiração de silêncio?" O fato é que os que se sentem "donos" de Nísia Floresta no Brasil têm sido incapazes de se comportar com o profissionalismo esperado de um pesquisador idôneo, valorizando mais seu nicho de expertise, que não admite correção, do que a verdade histórica. Continuam a alimentar uma inverdade. Imagine a que ponto se chega! No ano 2000, a Zahar publicou o Dicionário Mulheres do Brasil, e o verbete "Nísia Floresta" continua a dizer que ela traduziu Mary Wollstonecraft. Uma especialista em Nísia Floresta, com quem jamais me encontrei — a responsável pela edição de 1989 da tradução de Nísia e das notas explicativas ao texto, que contém alguns erros graves - após a divulgação de meu trabalho, em 1995, passou a reproduzir em seus escritos sobre Nísia minha descoberta sobre Poulain de la Barre e Sophie — sem mencionar meu nome ou meus textos —, mas continua, ao mesmo tempo, a divulgar o fato inverídico de que ela fez uma tradução livre e criativa de Wollstonecraft.

Atitude como essa é, no meu entender, inqualificável sob qualquer ângulo que se olhe, uma vergonha para a classe intelectual brasileira. Em qualquer país do mundo, um dicionário biográfico deve conter, na bibliografia, tudo ou quase tudo que foi publicado sobre o assunto, 
e não boicotar informações essenciais sobre o tema. Na bibliografia que acompanha esse verbete do ano 2000, o estudo mais novo listado é o de Constância Lima Duarte, de 1995, e não há nenhuma menção à publicação de meu livro do mesmo ano, Nísia Floresta: 0 carapuceiro e outros ensaios de tradução cultural, nem ao artigo publicado no Caderno Mais. Enfim, a "conspiração de silêncio" sobre o que efetivamente Nísia fez em 1832 é tão bem-sucedida em barrar o acesso à verdade que os editores do dicionário, por mais empenhados que estivessem em desvendar a história das mulheres desde o ano 1500 até a atualidade, não puderam ultrapassar aquela barreira no caso de Nísia Floresta. Mas, se, no âmbito brasileiro, o controle exercido pelos guardiões da "versão histórica" que lhes convém tem sido dominante, no âmbito internacional a situação é diferente, o que é desconcertante para nós, brasileiros.

\section{Dando os créditos...}

Sim. Estudiosos do feminismo latino-americano e internacional, que bem sabem que Mary Wollstonecraft só foi traduzida para o português há bem poucos anos, têm notado a intrigante permanência ou solidificação do que já foi chamado de "Mito Floresta-Wollstonecraft" e procurado demolir essa "conspiração de silêncio" orquestrada pelos principais estudiosos brasileiros de Nísia Floresta. Mas essa batalha pela verdade histórica não é simples. Como se luta contra aqueles que dominam, que se consideram donos do saber e que lançam mão de todos os meios, por mais escusos que sejam, para ocultar a verdade factual?

\section{A fortuna crítica da Nísia não reconhece essa sua pesquisa. E o fato de Nísia ter dito que a tradução era livre em relação a uma obra, mas, na verdade, ser a literal de outra?}

Fora pouquíssimas exceções, ao menos no Brasil, não se reconhece e continua a se repetir aquilo que não é verdade. Triste, muito triste. Inicialmente, achei - iludida — que minha descoberta fosse dar origem a uma discussão muito frutífera, muito rica; a um diálogo intelectual da maior relevância para a busca do conhecimento; que viesse a iluminar esse enigma da história do feminismo brasileiro. Enfim, não deu em nada, a não ser numa crítica violenta a mim, seguida de um silêncio sepulcral, como se nada tivesse acontecido. Isso é lamentável para o progresso do saber, do conhecimento. Espero que isso não se repita em muitas outras áreas. Claro que nisso tudo tem o lado pessoal, de sentir na pele um lado da comunidade intelectual que gostaríamos de acreditar que não existe. Mas, deixando de lado esse imenso desapontamento, estou pensando nas condições para o progresso do conhecimento e como explicar atitudes como essa que barram esse progresso. Enfim, essa foi a experiência mais negativa de minha vida acadêmica. 
Maria Lúcia, queria ouvi-la um pouco sobre sua experiência aqui na Inglaterra, na docência e na pesquisa, com um termo também de comparação com o Brasil, sua adaptação aqui. Como você vê o sistema universitário inglês? Como é essa sua experiência com relação ao ensino no Brasil e na Inglaterra, já que essa é uma alteridade tão importante, antes de a gente entrar em Gilberto Freyre?

Não tenho vínculo empregatício com a Universidade de Cambridge, mas sou pesquisadora associada do Centro Latino-americano, o que é uma posição muito confortável. Mas vamos começar pelo sistema universitário vigente aqui em Cambridge, que acho que é muito especial e inusitado. Devo dizer que conheço mais o sistema inglês desse lugar privilegiado em que estou, e o que vou dizer não vale para todas as universidades britânicas. 0 que me impressionou desde que cheguei aqui foi a variedade de possibilidades e a liberdade que existe na forma como o ensino é organizado. É muito livre. Uma marca distintiva do ensino, tanto de Cambridge quanto de Oxford — nunca fui ligada à Oxford, apesar de já ter estado lá várias vezes dando seminários - é a atenção individual dedicada aos alunos de graduação nos cursos de humanidades — nas outras ciências, não sei — , por meio de uma supervisão um a um. Aqui em Cambridge é um a um, tête-à-tête. Em Oxford, pelo que sei, há muitas vezes dois alunos para um tutor.

\section{Em se tratando de graduação, é algo surpreendente.}

Sem dúvida. Essa forma de ensino faz com que os alunos sejam, de certo modo, seus próprios mestres. Nos encontros com o tutor, os alunos se veem obrigados a discutir o trabalho semanal que preparam sozinhos, a justificar suas escolhas, a questionar os textos lidos e até as ideias do próprio tutor. Então, o ensino é baseado nesses tutorados e em aulas para o grupo maior, que não são obrigatórias. Vai quem quiser e não se faz chamada. Muitos alunos optam por assistir a essas aulas. Na experiência que tive, trata-se de uma palestra, em geral excelente, mas que os alunos dela não participam com perguntas e questionamentos de qualquer espécie. Não que isso seja proibido, porém não faz parte do ethos universitário. Discussões e debates são, em geral, confinados aos espaços dedicados a seminários.

\section{Essa ideia de cursos livres, da universidade livre...}

Nada impede que qualquer pessoa entre na sala e assista às aulas. Se se tiver a programação, que pode ser obtida em vários lugares, pode-se assistir a belíssimas aulas. Então, muitos alunos vão às aulas, mas não têm qualquer obrigatoriedade de ir. 0 básico e obrigatório no curso de humanidades é a conversa semanal com o tutor, como disse. Ele passa uma tarefa, alguma coisa sobre o que se tem de escrever. Em história, por exemplo, o tutor passa uma pergunta e o aluno deve responder se baseando, em parte, na bibliografia fornecida. 
O aluno escreve um pequeno ensaio sobre a questão ou o tema que pesquisou na biblioteca e também sobre o qual obteve ideias e informações nas aulas que optou por ir. 0 tutorado, em geral, tem como base aquilo que o aluno escreveu. A conversa com o tutor parte daí. Nas outras universidades inglesas, eles têm também um contato pessoal com algum tutor — vejo pelos meus filhos, que fizeram outras universidades - , mas não da forma tão sistemática e importante como acontece aqui em Cambridge e Oxford.

Outra coisa impressionante é a liberdade que se tem para obter colaboradores para uma universidade como a de Cambridge. Quando aqui cheguei, antes mesmo de ser pesquisadora associada do Centro Latino-Americano, orientei trabalhos. É impensável no Brasil, acredito, uma pessoa que chega de fora ser convidada para orientar o trabalho de um aluno de uma universidade como a de Cambridge. Tive essa experiência tão logo aqui cheguei. Uma pessoa que conheci era diretor de estudos de um college. Como ele ficou sabendo de meu trabalho sobre o Spectator e o jornalismo, ouviu-me dando seminários, achou que eu poderia colaborar com a universidade.

Foi assim que um dia recebi uma cartinha dizendo: "Maria Lúcia, gostaria que você fosse supervisora de tais e tais alunos." Eu supervisionava os trabalhos de curso de alunos da Universidade de Cambridge sem nenhuma burocracia, sem carteira assinada, sem ter nenhum vínculo empregatício. 0 que eu tinha de fazer era mandar no fim do mês, aos colleges respectivos, as horas que havia atendido tais e tais alunos para receber o pagamento que me era devido. Então, é uma abertura que deve explicar um pouco da qualidade e da excelência dessa universidade ou de universidades semelhantes. Abertura que se vê inclusive no número de professores e alunos estrangeiros que compõem os quadros docentes e discentes.

Você sabia que a Universidade de Cambridge tem mais de noventa prêmios Nobel? No nível de pós-graduação, em especial, o recrutamento internacional de alunos permite que as discussões e os seminários sejam muito enriquecedores, trazendo vários pontos de vista, um diálogo muito rico. Acho que essa variedade de alunos, sobretudo na pós-graduação, mas também um pouco na graduação, é muito produtiva. Mesmo antes de alguns países do leste europeu pertencerem à comunidade europeia, muitos colleges promoviam a vinda de estudantes dessa região, dando bolsas, pagando passagem, estadia...

\section{Estimulavam a vinda...}

Exatamente. Acho que essa abertura explica muito da excelência de Cambridge e Oxford, o fato de estarem sempre nos primeiros lugares na liga das universidades. Não sei medir quanto essa internacionalidade pesa nisso tudo, mas não dá para dizer que isso não é bastante significativo. 
É a combinação seja da dimensão estrutural que se abre para os docentes de excelência, seja da experiência multicultural no âmbito acadêmico, com uma pluralidade de origens nacionais.

Exatamente. Isso tudo contrasta com o modo muito mais rígido e burocrático do sistema brasileiro. Ontem mesmo o Peter estava recordando quando foi convidado pelo Instituto de Estudos Avançados da USP. Ele dava cursos no IEA, e quando chegou o fim do mês lhe pediram o certificado de doutorado. Em nenhum currículo que ele mandara constava que fosse doutor. Ele falou mais ou menos o seguinte: "Não tenho, nunca tive esse título. Não fiz o doutorado. Eu o interrompi quando me chamaram para trabalhar na Universidade de Sussex. Meu orientador [que era Hugh Trevor-Roper] me disse, quando soube do convite: 'Esqueça o doutorado e vá para Sussex. Publique seu livro sem doutorado, que é muito mais importante."' Naquele momento, quando Sussex fora recém-fundada, havia muita semelhança entre ela e Oxbridge. Havia até um professor de história da arte que não tinha bacharelado, mas que era considerado uma figura eminente na sua área, o que bastava para ser contratado.

Não ter doutorado e ser um professor titular não era tão raro naquela na época. Vários grandes scholars, como Keith Thomas, Christopher Hill, Hugh Trevor-Roper, Quentin Skinner, Roger Chartier, nunca tiveram esse título. A produção deles era de tanta qualidade que eram contratados pelas universidades sem qualquer exigência formal. Havia, pode-se dizer, até certo esnobismo em não ter o doutorado.

Enfim, o Peter não tinha um papel para mostrar e foi uma confusão no IEA. Como iriam pagar a alguém sem diploma? Levou um tempo até chegarem à conclusão de que o melhor a fazer era lhe dar o título de professor de notório saber, com o qual ele pôde receber o pagamento que the era devido. Isso acho muito ilustrativo da rigidez do sistema brasileiro e de tantos outros. Algo semelhante aconteceu na Espanha pouco depois. Acho que essa abertura, essa liberdade, que o sistema daqui tem explica ao menos parte da excelência desse ensino, dessa universidade.

Queria que você falasse também sobre a experiência do Clas e sua visão acerca dessa área que o Brasil não cultiva tanto, mas que na Europa é forte, dos african studies e dos latin-american studies. Como vê essa área de estudos latino-americanos, as associações de pesquisa e os pesquisadores britânicos ou americanos que se interessam pela história da América Latina? E também sobre a presença de pesquisadores brasileiros em universidades dos Estados Unidos e do Reino Unido.

Não sei se o que sei é amplo o suficiente para Ihe dar uma resposta adequada, mas, falando especificamente do Clas, é um centro muito dinâmico, onde se reúnem estudantes não só de várias disciplinas das humanidades, como história, antropologia, literatura, unidas pelo interesse na América Latina, mas também de várias origens. Essa variedade 
de pessoas vindas de várias disciplinas, aliada à diversidade de suas origens, engrandece sobremaneira as discussões, os trabalhos, trazendo, por exemplo, vários pontos de vista para os seminários semanais.

\section{Os estudos latino-americanos começam a se estruturar no Reino Unido por volta dos anos 1960. 0 Clas é um pouco posterior. Você tem ideia de quando, especificamente, foi criado?}

Foi criado em 1966, e, como muitos outros centros dedicados ao estudo da África e da Ásia — criados, a maioria, nos anos 1950 - , foi o resultado da conjuntura geopolítica após o fim da Segunda Guerra Mundial. A América Latina não foi, no entanto, objeto de significativo interesse no Reino Unido até meados dos anos 1960, quando o Parry Report, elaborado por um Comitê Parlamentar e publicado em 1965 — na sequência da Revolução Cubana e do Programa Aliança para o Progresso inaugurado pelo presidente Kennedy —, considerou questão de "importância nacional" o estudo da América Latina. Foi assim que o governo proveu fundos para a criação de Centros de Estudos Latino-Americanos em Cambridge, Glasgow, Liverpool, Londres e Oxford. Quanto aos alunos, diria que compõem um grupo heterogêneo, mas a grande maioria, ao menos em Cambridge, é composta de nativos ou de origem latino-americana. Diria, no entanto, que as regiões que fizeram parte do Império Britânico ainda continuam a atrair mais a atenção dos alunos de Cambridge. Após a queda da União Soviética, os países do Leste Europeu começaram também a atrair muito interesse e fundos para pesquisas, portanto os estudos latino-americanos têm de competir com muitos outros em fundos e número de interessados.

Posso estar enganada, mas, entre os estudos latino-americanos, o que mais atrai interesse, pelo menos aqui em Cambridge, é o México. Não sei se tem a ver com o fato de David Brading, um grande estudioso do México aqui na Inglaterra, ter sido diretor do centro, mas tenho essa sensação também em Oxford. Talvez a proximidade com os Estados Unidos explique essa preferência, não sei.

\section{Isso do ponto de vista dos alunos que vêm se titular numa prestigiosa universidade e do ponto de vista do corpo docente?}

É variado. Agora, por exemplo, há a Gabriela Ramos, que é do Peru, e o Pedro Mendes Loureiro, do Brasil, recentemente contratado. A Gabriela é uma excelente historiadora, várias vezes premiada, que estudou no Peru, nos Estados Unidos, e veio para cá já há vários anos. 0 que acontece é que a maior parte dos professores, se não todos, que dão aula para os alunos do Clas estão vinculados a vários departamentos. A Gabriela está ligada ao departamento de história; o Pedro, ao de ciência política, assim como tantos outros que não são exclusivos do Clas. 


\section{0 centro não é uma estância departamental, digamos assim?}

Seria, por assim dizer, um departamento interdisciplinar. 0 que existe também de muito interessante é a cadeira Simon Bolívar, fundada em 1968 e patrocinada pelo governo venezuelano, para trazer anualmente uma figura eminente do mundo latino-americano. Mario Vargas Llosa, Octavio Paz, Celso Furtado, Carlos Fuentes José de Souza Martins, Antônio Sérgio Guimarães e Fernando Henrique Cardoso já foram Simon Bolivar professors. Uma das vantagens desse centro, no meu entender, é que os brasileiros têm a oportunidade de ver o Brasil como parte da América Latina. Posso estar defasada, mas quando eu estava no Brasil não era comum colocar o país como parte da América Latina. Os olhos brasileiros eram normalmente mais voltados para a Europa e os Estados Unidos. Enfim, acho que o Clas para os brasileiros tem esse grande papel.

Para além dos brazilian studies, a perspectiva é mais ampla de uma escala regional, e não apenas nacional.

É um centro pequeno, menor do que o centro de Londres, com o qual tive algum contato. O que ouço também é que, ultimamente, muito do interesse que se tinha pela América Latina foi desviado para a Europa do Leste, para a China e para os Estados que saíram da União Soviética. Parece que isso está tirando não só a atenção da América Latina, como também as verbas que poderiam ser destinadas ao seu estudo. Isso é um fenômeno relativamente novo.

Agora podemos nos concentrar nos seus estudos sobre a obra de Gilberto Freyre. Minha primeira questão seria em torno do princípio do seu interesse: como você o descobre? Por que ele a cativa? A partir dos anos 2000, seu trabalho sobre a obra dele começa a ser publicado. Como é esse interesse, vamos dizer, sistemático em torno do pensamento de Gilberto Freyre?

Meu contato com a obra de Freyre começou tardiamente, muitos anos após eu ter terminado a faculdade. Enquanto estudante, muitos como eu não se interessavam - algo tolo, admito - em ler um autor comprometido, como se sabia, com a ditadura militar. Estranhamente, foi o Spectator que me levou a Freyre. Mas meu primeiro trabalho sobre ele foi para a Brasa [Brazilian Studies Association], em 1996.

\section{Que aconteceu em Cambridge...}

Isso. 0 Peter foi a pessoa a quem o diretor, David Lehmann, pediu que pensasse em organizar alguma mesa na Brasa. Como ele tinha muito interesse em Freyre, que remontava a muitos anos antes de me conhecer, resolveu fazer uma mesa discutindo Freyre e me perguntou 
se eu não queria participar. Já nos anos 1960, ele não só lera várias obras de Freyre, como também havia se encontrado com ele durante uma palestra em Sussex, convidado pelo reitor Asa Briggs, grande admirador de Freyre. Foi assim que resolvi pensar sobre algum aspecto do pensamento freyreano e escrevi meu primeiro artigo sobre ele, Gilberto Freyre e a Inglaterra: uma história de amor, que publiquei pouco depois desse encontro de 1996.

\section{Considerando que você publicou em 1995 sobre a Nísia...}

É, foi logo depois. Interessante que Freyre se referiu a Nísia nos trabalhos dele. Esse meu primeiro artigo focalizava o interesse que ele tinha pela Inglaterra, mas dava muita ênfase à questão do ensaísmo freyreano e sua inspiração britânica. No ano 2000, por conta dessa publicação - e o Peter também, pelo que já havia publicado sobre Freyre —, nós dois fomos convidados para ir à comemoração do centenário do nascimento do Freyre, em Recife. Foi um belíssimo evento, uma conferência com pessoas de várias partes dos Estados Unidos e da Europa, que haviam estudado vários aspectos do pensamento e da ação de Freyre. Foi nessa ocasião que, levada pelo que pude suspeitar quando xeretei a biblioteca de Freyre em Apipucos, tomou forma a ideia de escrever um livro sobre a trajetória intelectual do jovem Freyre, salientando o papel que as ideias e os autores britânicos exerceram em sua formação, já que fui ficando fascinada e intrigada pela presença de marcas inglesas em sua obra e pela sua confessa e reiterada anglofilia.É interessante saber como, literalmente, cheguei a ele. Eu estava escrevendo meu doutorado quando um grande amigo, João Hansen — sabendo que eu estava interessada na questão da cultura inglesa, sua relação com Brasil e o fenômeno da circulação das ideias —, me falou: "Você conhece esse livro?" Era Ingleses no Brasil, que eu não conhecia. Foi esse o primeiro livro que li de Freyre, nos anos 1980. Na época eu estava escrevendo meu doutorado, e logo depois voltei ao Ingleses no Brasil, porque, ao folheá-lo, eu havia deparado com o fato, salientado por Freyre en passant, de que o Spectator deveria ser visto como um dos agentes da cultura britânica no Brasil do século XIX.

\section{Ele diz isso?}

Diz. Tanto que, como os brasileiros tinham o hábito de dar aos filhos nomes de pessoas ilustres que admiravam, havia na época, no século XIX, muitos Addison no Brasil. Joseph Addison é o nome de um dos dois jornalistas que produziram o The Spectator. Fiquei impressionada com essa informação e resolvi escrever para o Freyre, mas pensando que ele não fosse me responder. Mandei uma carta para Apipucos dizendo o que eu estava fazendo, que eu descobrira que ele mencionara o Spectator no livro Ingleses no Brasil e queria saber se tinha mais alguma informação. Para minha surpresa, logo recebi uma resposta, que começava assim: "Minha cara colega de estudos...", nunca vou me esquecer dessa carta. Logo depois que terminei o doutorado, comecei a ler com mais vagar Ingleses no Brasil, livro que me 
descortinou dimensões insuspeitas sobre a influência da cultura britânica no ethos brasileiro. Fiquei entusiasmada com o modo com que Freyre trazia à luz o papel dos "marias-borralheiras" britânicos na história do Brasil e com a forma inovadora com a qual tratava o processo de interpenetração de culturas, abrindo espaço para que houvesse muito mais do que a imposição de uma cultura mais rica e poderosa sobre outra mais fraca e subalterna. Também li nessa época um livrinho chamado Os ingleses, publicado em 1942, que é uma coleção de ensaios de Freyre sobre vários aspectos e nomes da cultura britânica, que ele chamava de "inglesa". Foi assim que eu, por assim dizer, entrei no universo freyreano pela "porta dos fundos", lendo um livro muito pouco conhecido que ele publicou em 1948.

\section{Freyre falece em 1987, em torno desse período que você está terminando o doutorado.}

Ele já havia falecido quando comecei a ler com maior atenção e interesse as obras dele. Escrevi um ensaio, que foi primeiramente apresentado na Brasa, como disse, sobre a importância do ensaio na obra do Freyre, e como isso estava ligado a seus interesses pelos ingleses. 0 artigo, que surgiu daí, foi publicado na revista Tempo Social e, pouco depois, em versão inglesa, na revista The European Legacy. Quando fui a Recife em 2000, já estava amadurecendo a ideia de escrever uma obra sobre o período formativo de Freyre, sem ainda saber que a biblioteca em Apipucos me forneceria pistas maravilhosas para isso. Uma coisa de que agora me dou conta é que tenho um especial interesse por estudar o período formativo, aquilo que faz alguém se tornar ou realizar aquilo pelo qual depois ficou famoso. 0 que aconteceu com Anísio Teixeira, por exemplo? Oriundo de uma família oligárquica baiana, destinado pela sua educação a ser um jesuíta, o que o teria feito abandonar a carreira religiosa para a qual parecia predestinado e transformar a educação na sua religião? 0 que aconteceu para que ele, de repente, ainda muito jovem, desse essa "virada"?

\section{No caso de Freyre, parece que existe também um paralelismo com sua própria trajetó- ria, porque o período formativo dele é o mundo anglo-saxão. De alguma forma, você também teve a experiência nos Estados Unidos e depois a experiência na Inglaterra...}

É, às vezes me pergunto se eu poderia ter escrito esse livro se não morasse aqui. Acho importante o lugar de onde se fala, de onde se está. Esse livro sobre os anos formativos de Freyre também estava ligado muito a essa pergunta sobre o que teria feito um indivíduo que, quando jovem, compartilhava com a elite os preconceitos da época contra o mestiço, vendo-o como um elemento que impedia o progresso do Brasil, mudar drasticamente de atitude. 0 que teria feito ele, aparentemente de repente, se impor como um defensor da mestiçagem, mudando o parâmetro com o qual se pensava o Brasil e transformado o que era tido como uma desvantagem em vantagem? Em 2000, quando eu estava em Recife, xeretei a biblioteca, 
folheei os livros e vi que o que era extremamente valioso na biblioteca de Freyre eram os livros que haviam sido adquiridos por ele quando jovem e lidos no seu modo, por assim dizer, "descuidado".

\section{Na Fundação Joaquim Nabuco?}

Não, na própria Fundação Gilberto Freyre, que fica na casa que Freyre viveu em Apipucos. Folheei e vi que eram livros que haviam sido dele, que ele lera exatamente aquele livro, aquele exemplar. Voltando para a Inglaterra, consegui grant da British Academy para voltar a Recife, e lá fiquei algum tempo pesquisando exatamente esse período formativo de Freyre e as leituras que ele fez, lendo, pegando os livros que ele leu — os próprios livros - e verificando todas as marcas que ali deixara.

\section{0 que se chama em letras de crítica genética...}

Tentei escrever uma biografia genética acompanhando seu desenvolvimento, e não vendo a coisa de trás para frente, não partindo, pois, da ideia de que ele era o grande escritor de Casa-grande \& senzala. Tentei acompanhar seus passos, suas indecisões, seus desafios, seu "namoro" com a Ku Klux Klan, por exemplo — enfim, como suas ideias foram sendo desenvolvidas passo a passo, tentando verificar os passos determinantes.

Porque até então o núcleo dos interesses, das argumentações, em torno da obra de Freyre estava focado nas ideias de Casa-grande \& senzala. Não havia esse estudo minucioso sobre a constituição mais abrangente desse pensamento. $E$, talvez de novo, 0 paralelismo me parece forte, 0 interesse dele pelo mundo anglo-saxão e sua vivência nesse ambiente cultural acadêmico, o fato de você também poder rastrear referências que aqui eram mais familiares do que no Brasil. Isso contribui para você fazer essa reconstrução mais minuciosa.

Tem razão. 0 que você menciona, acho realmente relevante. Uso um fragmento de um ensaio do Chesterton [Gilbert Keith] para falar sobre Freyre e a importância de seu afastamento do país. Aquela história de que o amigo chega e lhe pergunta: "Aonde você está indo?" Chesterton estava em Battersea, que é um bairro de Londres, com as malas prontas para partir. "Vou para Battersea." Ao que o amigo replica: "Mas você já está em Battersea." Chesterton, então, lhe diz mais ou menos o seguinte: "Todo objetivo de viajar não é pôr os pés em terras estrangeiras, mas pôr os pés em nosso próprio país como se fosse uma terra estrangeira. 0 único meio de chegar à Inglaterra é ir para longe dela." Enfim, ele tinha de sair de Battersea para chegar a Battersea. Acho que com Freyre foi isso. A trajetória dele mostra a força dessa visão de longe que se junta com a de dentro e produz, algumas vezes, algo inovador e valioso. 
Acho que isso, de certo modo, se aplica a qualquer pessoa que passa a ver o próprio país de longe. Vê-se sob outros ângulos, com diferentes perspectivas. No meu caso, é difícil avaliar, mas talvez se eu estivesse no Brasil, escrevendo com base na minha experiência só de lá, meu livro sobre a trajetória de Freyre não fosse exatamente o mesmo.

\section{Com todas essas referências que você descreve dele em 0xford, imagino que pesqui- sando daqui foi possível uma maior familiaridade.}

Os desafios que tive de enfrentar para escrever essa biografia intelectual do seu período formativo foram grandes. Por estar buscando seus tateamentos, suas indecisões, os obstáculos que ele teve de superar, os desafios que teve de enfrentar, verifiquei que ele havia compartiIhado as ideias racistas mais extremas em voga nos Estados Unidos que conheceu a partir de 1918. Ou seja, que os preconceitos com que saíra do Brasil haviam aumentado significativamente, por algum tempo, com o que encontrou lá fora em total ebulição. Ele chegou a escrever com simpatia sobre o Ku Klux Klan e outros defensores da democracia branca nos Estados Unidos, mesmo quando voltou para o Brasil após cinco anos de ausência.

\section{Da Universidade de Baylor, não é?}

O elogio que Freyre fez a Tillman [Benjamin], um dos mais brutais defensores da "democracia branca", por exemplo, era, por assim dizer, nada menos que chocante. Assim como também era sua admiração pelos programas norte-americanos para a "melhoria da raça", muito inspirados na assim chamada "ciência da raça" e na sinistra pseudociência da eugenia. Um dos desafios que eu tinha de enfrentar era o seguinte: o grande defensor da mestiçagem no Brasil, Gilberto Freyre, poucos anos antes de publicar seu Casa-grande \& senzala, via com simpatia a Ku Klux Klan e Tillman. Como apresentar isso com sabedoria e compreensão?

\section{Referi-me à Universidade de Baylor, que é a experiência que ele tem no Sul dos Esta- dos Unidos, antes de ir para Columbia, que também é um dos focos narrativos dessa inflexão, quando ele trava contato com o antropólogo Franz Boas.}

Exatamente. Mas um contato com esse grande intelectual muito menos importante na época do que ele quis fazer crer depois, porque posso dizer, com quase $100 \%$ de certeza, que Freyre descobriu Franz Boas mais tarde, e muito pela influência de Rüdiger Bilden. Bilden, 0 amigo que Freyre conheceu na Columbia University, era não só discípulo como amigo pessoal de Franz Boas. Apesar de, com o passar do tempo, Freyre querer dar a impressão de que tivera uma relação próxima professor-aluno com Boas, as evidências apontam o contrário. Uma carta de Boas ao seu ex-aluno Herskovits [Melville Jean] deixa claro que, tendo sido um entre centenas e centenas de alunos, e não seu orientando, Freyre não deixara nenhuma impressão 
em Boas. 0 nome de Freyre não era nem sequer lembrado por Boas em 1936, e ele não tinha nenhuma ideia de quem se tratava.

\section{Não tinham essa intimidade.}

Seguramente não. As ideias de Boas foram absorvidas e digeridas por Freyre lentamente, fruto de conversas com Bilden e de leituras feitas com mais cuidado após sair da Columbia University e voltar para o Brasil. Não foi, portanto, uma conversão imediata, como Freyre sugeriu no seu prefácio de Casa-Grande, em 1933, como querendo dizer: "Conheci Boas e me transformei em outro homem." Foi um grande desafio trabalhar com essa crença de Freyre no racismo cientifico, algo que, até então, salvo engano, não era conhecido. Ao menos para mim e para muitos dos meus leitores e resenhistas, foi uma surpresa. 0 segundo desafio era enfrentar a questão da homossexualidade, sobre a qual...

\section{...silenciava.}

Exato. Ou os estudiosos silenciavam-se ou o próprio Freyre queria trazer o tema à tona, mas o editor José Olympio não deixava. No momento que descobri aquele livrinho, lindo, encadernado em vermelho, muito bem acondicionado, guardado por Freyre com todo o cuidado durante décadas e contendo o poema de Linwood Sleigh, senti que havia descoberto um tesouro, um tesouro para o próprio Freyre. Não sou estudiosa de poesias homoeróticas, mas me parecia claramente uma poesia de amor entre dois homens. Pouco tempo depois dessa descoberta, eu estava no Instituto de Pesquisas do Goethe Center, em Los Angeles, Califórnia, e um dos fellows de lá nesse ano era Jonathan Weinberg, um estudioso desse tema. Jonathan é um artista e também um historiador da arte, de Yale, que escrevia na época o livro Male Desire: the Homoerotic in American Art, publicado pouco depois.

Quando me vi com aquele material, pensei: "Bom, vou ter de conversar com alguém muito entendido no assunto", pois me dei conta de que ou eu escreveria com muito conhecimento sobre a questão da homossexualidade naquela época, naquele ambiente de Oxford, para então chegar a essa figura humana de carne e osso que vivera uma experiência significativa e tratá-la com tato, seriedade e compreensão, ou não deveria abordar o assunto. Tratar de forma superficial um assunto tão delicado era ser leviana. Procurei Jonathan Weinberg, marquei um almoço e mostrei o poema que Freyre guardara como se fora um tesouro. Jonathan me passou referências bibliográficas importantes, deu-me informações fundamentais sobre a história da poesia homoerótica, mas me alertou que, por sua experiência, por mais sério que fosse meu trabalho de investigação, as críticas a essa intrusão seriam imensas. "Vou the dizer uma coisa, Maria Lúcia: por mais cuidado que você tenha, por mais pesquisa que faça, não vão entendê-la. Os estudiosos vão cair em cima de você. Pense bem." 


\section{A família de Freyre também...}

Sim, pensei que estivesse entrando num campo difícil, mas decidi enfrentar o tema com a dignidade que Freyre queria que ele fosse tratado, não me importando com a recepção. Nas próprias palavras de Freyre, ele vivera em Oxford "uma breve aventura de amor homossexual, no melhor sentido da expressão, sem canalhice alguma", e essa aventura, que, como ele disse, foi "lírica, além de sensual", o fizera experimentar o "amor na sua plenitude e na sua diversidade de expressão". Apesar de ser difícil aquilatá-los com exatidão, não se podem minimizar o impacto emocional e estético que esse encontro teve no desenvolvimento de Freyre e suas repercussões em sua trajetória intelectual. Estou convencida de que o caráter da sensibilidade de Freyre e seu interesse e percepção artística foram indelevelmente marcados pelo encontro com esse jovem inglês que crescera imerso num rico ambiente artístico pré-rafaelita. $A$ descoberta que Freyre fez de todo um determinado universo artístico britânico — Rossetti, pré-rafaelitas, William Morris etc. — que se mostrará essencial para seu pensamento e sua ação ao retornar ao Brasil, remontava a esse encontro efêmero, mas muito significativo, com o jovem Linwood Sleigh, filho de um artista pré-rafaelita e, ele próprio, um artista talentoso.

\section{0 mesmo se diz sobre a relação entre ele e José Lins do Rego, com insinuações da amizade entre os dois.}

Sim, li muitas dessas cartas trocadas entre Lins do Rego e Freyre após sua volta a Recife, e concordo que a amizade entre eles, pelo que se pode perceber nessas trocas, era também muito especial. Bem, tão logo o livro foi publicado, tive uma grande surpresa quando saiu a primeira resenha do livro Gilberto Freyre: um vitoriano dos trópicos, publicada, se não me engano, no Diário de Pernambuco...

\section{...o livro saiu em 2005}

Sim, no finalzinho de 2005. Essa primeira resenha foi escrita pelo grande historiador Alberto da Costa e Silva, africanista famoso, grande homem. Nunca mais achei a resenha, preciso procurar, mas foi o maior presente que eu poderia receber. Ele dizia mais ou menos assim: "A parte mais bonita do livro é quando a Maria Lúcia trata da questão homossexual em Gilberto Freyre, que eu gostaria de ter escrito." Falei para mim mesma: "Bom, já ganhei um prêmio." De verdade, essa recepção foi, para mim, meu primeiro e inesperado prêmio.

\section{Porque o livro foi premiado depois.}

Foi premiado pela Academia Brasileira de Letras (Premio Senador José Ermírio de Morais) e pelo Jabuti. Mas o primeiro grande prêmio foi essa resenha do Alberto da Costa e Silva, que na época tinha mais de setenta anos. Refiro-me à idade porque seria compreensível que ele 
carregasse toda a marca de uma formação mais conservadora e não apreciasse minha abordagem sobre a homossexualidade do jovem Freyre.

Havia o temor de que você seria atacada, porque tocou nesse tema-tabu. De fato, é uma pesquisa desenvolvida a fundo. Freyre foi reconhecido por ser um inovador da historiografia, ao trazer a cultura material e as novas fontes para sua obra. Um vitoriano dos trópicos chama a atenção pela vasta documentação que você conseguiu levantar não só no Brasil, mas nos Estados Unidos, onde ele residiu. Também há o trabalho da Maria Lúcia historiadora que faz jus a uma obra tão grande. Então, eu queria que você comentasse um pouco sobre sua metodologia, porque ali também há sua formação como historiadora. Você, em 2000, publica o livro As muitas faces da história, coletânea de entrevistas com historiadores contemporâneos de ponta, reconhecidos e que atuam nessa área da história cultural. Eu queria que você falasse da metodologia de pesquisa para um livro tão denso, com fontes primárias e que resultou nessa obra tão impressionante.

Tenho dificuldade para falar de "meu método", pois penso que tudo depende das fontes disponíveis para cada tema que se estuda. Mas há também uma escolha prévia, antes de se buscarem as fontes. No meu caso, por estar interessada no processo de formação de Gilberto Freyre (e de Rudiger Bilden), isso estabelece a "cena" a partir da qual certas fontes são vistas como essenciais. Não estava, portanto, interessada primordialmente em fazer um estudo crítico de sua obra, e sim em escrever uma biografia desenvolvimentista ou genética. Tendo isso em vista, mergulhei no vasto material que existia - grande variedade desse material encontrado na Fundação Gilberto Freyre de Recife — , o qual incluía centenas de cartas, quarenta volumes de recortes de jornal e de revistas contendo referências de todo tipo à obra de Freyre, bem como as anotações feitas por Freyre em seus livros, que foi a fonte mais rica e valiosa para o tipo de livro que escrevi sobre o período formativo do jovem Gilberto.

Minha pergunta principal, ou melhor, o "problema" que me interessou ou me impulsionou, por assim dizer, foi o seguinte: como explicar que um livro como Casa-grande \& senzala - fundamental para transformar a autoimagem do Brasil e lhe injetar a autoestima de que carecia - tivesse sido escrito por um jovem brasileiro que, como tantos outros brancos de sua época, se orgulhava dos ancestrais europeus que haviam se tornado parte da elite do país, que compartilhava com sua classe os preconceitos contra a população negra e mestiça e que sentia também uma profunda frustração por ser brasileiro, para lembrar o sentimento amplamente disseminado entre a elite que Paulo Prado tão bem explorou em seu livro Retrato do Brasil — um sentimento que Freyre bem cedo manifestou ao claramente lamentar: "Por que não nasci inglês, ou alemão, ou americano...?" Mas, além dos livros manuseados por Freyre, a correspondência que encontrei em Apipucos foi também fundamental para o trabalho que desenvolvi. 
Essa é a fonte primária que mais me chama a atenção e que também não é uma fonte primária fácil.

Não, nada fácil, porque às vezes, ou a maioria das vezes, não se tem toda a conversa; apenas um pedaço dela. Se a conversa por cartas acontece regularmente, fica mais fácil supor o que a outra pessoa escreveu. Quando, no entanto, a correspondência é irregular ou se tem somente uma ou poucas cartas, a dificuldade aumenta. Enfim, é necessário muito cuidado para não se assumir o teor de toda a conversa. No caso de Freyre, tive acesso ao outro lado da conversa quando descobri em alguns arquivos, como de Francis Simkins, cartas enviadas por Freyre. Mas foram casos relativamente raros.

É manuscrita, é uma lida que requer muito. Não que tenha havido uma mudança do seu perfil como pesquisadora, mas é um mergulho, como você diz.

Foi um desafio muito grande dar um sentido àquele volume imenso de material, aos milhares de recortes de jornal, muitos deles quase ilegíveis, contendo referências de todo tipo à obra de Freyre. Havia também um número incrivel de papéis avulsos, caderninhos, coisas de todo tipo, pois Freyre guardava tudo. Na verdade, devo agradecer a Freyre a possibilidade de escrever uma obra como a que escrevi, porque ele, ao que tudo indica, guardava mesmo aquilo que poderia vir, eventualmente, a macular sua imagem. Ou seja, Freyre não seguiu o exemplo de tantos outros grandes homens que tentaram dificultar o trabalho de futuros biógrafos. Para mencionar alguns exemplos, Freud, Henry James, Charles Dickens e Thomas Hardy destruíram — ou deixaram ordem expressa para que fosse destruída após sua morte — toda a documentação que poderia ajudar a reconstruir suas trajetórias. Assim, não obstante sua notória vaidade e seu desejo de ser visto positivamente pela posteridade, Freyre não fez uma fogueira de seus papéis porque tinha uma aguda consciência da importância dos documentos históricos e desde cedo considerava tudo digno de ser preservado, desde cardápios de restaurante e entradas de teatro até cartas contendo duras críticas à sua pessoa. Considerando a montanha de papéis que existe em Apipucos, ainda resta muito a ser descoberto, e estou longe de dizer que exauri as possibilidades de trabalho.

Se você se ativesse à obra publicada dele já seria uma enormidade, se pensarmos as inúmeras edições que se seguiram dessas obras em que ele sempre apresentava um novo prefácio. É realmente uma obra vasta e volumosa. Em geral, o pesquisador quer se equipar do máximo possível para poder falar com propriedade. Como você dá conta das obras completas, da fortuna crítica e das fontes primárias?

Penso que dar conta de tudo isso, de modo exaustivo, é uma ilusão. Não só porque novas perguntas podem provocar a descoberta de novas fontes, mas porque a quantidade é tal que 
precisaríamos de muitas vidas para realizar uma pesquisa exaustiva. 0 que também é interessante anotar para futuros pesquisadores é que, na Fundação Gilberto Freyre, há quatro volumes, organizados pela Magdalena, mulher dele — minha suposição é que tenham sido organizados contra a vontade dele - , que contêm tudo o que ela achava que era hostil a ele: resenhas, comentário de qualquer tipo, artigos de jornal, que ela via como críticas ao marido, e assim por diante. Para mostrar seu desagrado, ela deu aos quatro volumes o título de WC (water closet): privada. É um material interessante e está todo lá para ser lido. Enfim, não há falta de material.

Minhas fontes básicas foram essas a que estou me referindo e os livros de Freyre. Os livros que ele leu, com as marcas que deixou. Às vezes ele fazia uma marca com a unha; noutras, riscava com um lápis; e volta e meia fazia um comentário como "like in Brasil". No tempo em que estive na Fundação Gilberto Freyre, eu trabalhava horas a fio examinando sua obra e procurando suas marcas. Não lia propriamente os livros, porque não haveria tempo para isso e eu podia lê-los aqui. Eu focava em anotar as marcas que ele fizera na página tal da edição tal, para poder recuperar depois exatamente o trecho que havia lhe chamado a atenção.

\section{0 propósito era reconstituir o método, os interesses de leitura, o universo do qual ele partia.}

Mais do que reconstituir o método de Freyre - que se caracterizava desde sempre como antimetódico, impressionista ou "desleixadamente ensaístico", como já foi dito — , minha preocupação era recuperar suas leituras, seus interesses e o impacto que os ensaístas, que descobriu primeiramente na Universidade de Baylor, tiveram em sua formação. Para isso, os diários da juventude — diários de verdade, não o "diário" que depois ele publicou em 1975 —, que nada mais eram do que anotações que ele fazia de modo assistemático em qualquer papel avulso, registrando ideias, comentários e trechos inspiradores, foram achados preciosos para a biografia desenvolvimentista que estava escrevendo. Há anotações lá dos anos 1920, 1921, e numa delas ele escreve essa frase reveladora: "A verdade é como a esposa adúltera — ora com o esposo, ora com o amante. Flutua. Oscila entre os dois. Não há razão. Há razões. A razão está um pouco em toda parte. A razão? Uma mina aonde qualquer pode ir, com sua picareta, extrair razões." Em outro caderninho, ele confessa a razão pela qual não queria se radicar nos Estados Unidos: "Posso andar em inglês, porém não dançar na ponta dos pés; tenho de contentar-me em andar — mais nada — , e assim mesmo mal." Enfim, para dançar com a língua, uma ambição que se manifesta muito cedo, Freyre reconhece que tinha de escrever em português.

\section{Ele fica cinco anos e volta em 1923.}

Sim, e quando volta ainda não era o Freyre que a gente conhece como o grande defensor da mestiçagem. Para isso ainda teria de caminhar bastante. 0 período formativo de Freyre é muito cativante, é muito fascinante acompanhá-lo. 


\section{Há o Manifesto Regionalista, que também causa várias polêmicas. Até o contraponto que ele faz com o modernismo de São Paulo, em que demarca essa ideia do Nordeste, da região, da tradição. E, ao mesmo tempo, é um cosmopolita.}

Alguns aspectos dessa polêmica podem ser muito relativizados. Já desde antes do Manifesto Regionalista, Freyre estivera envolvido na defesa do regionalismo e das tradições locais, ao lado de outros artistas e jovens intelectuais que se definiam contra certo tipo de modernismo. Para eles, a rejeição ao passado não era um passo necessário no caminho da modernização - processo que poderia perfeitamente admitir tradições brasileiras ou locais em arquitetura, culinária, valores patriarcais, e assim por diante. 0 contraste acentuado, sempre muito lembrado, entre o chamado movimento tradicionalista e regionalista, liderado por Freyre, e o movimento modernista e internacionalista de São Paulo, liderado por Mario de Andrade, pode ser visto como falso. 0 jovem Freyre mostrava muita simpatia pelo modernismo e também pela modernidade, desde que ela respeitasse o passado. E os modernistas de São Paulo, que não desejavam se afastar totalmente da tradição, queriam criar uma forma distintamente brasileira de modernismo, o que significava buscar subsídios nas tradições locais - coloniais, indígenas ou africanas —, em vez de abandoná-las por completo.

\section{0 filme de Joaquim Pedro [de Andrade], 0 mestre de Apipucos [curta-metragem de 1959], o mostra como um aristocrata.}

Não conheço esse filme, mas essa ideia de Freyre aristocrata e muito rico foi bem difundida por muito tempo, e talvez ainda esteja viva em certos círculos. Mas a verdade é que ele não era nada rico, nunca foi rico. A casa que morou desde 1941, se não me engano, e onde está instalada a Fundação Gilberto Freyre, é uma casa bonita, estilo colonial, que ele comprou e transformou aos poucos numa pequena mansão, colocando inclusive azulejos coloniais que trouxe de Portugal.

Lembro bem, contudo, quando a Sônia [Freyre] nos mostrou a casa toda e chegamos ao quarto de Freyre. Era um quarto grande, do tamanho dessa sala, talvez um pouco maior, onde estava sua cama, seus guarda-roupas etc. Ela disse: "É aqui que vivíamos, todos nós. Este era o quarto da família. Só havia um quarto na casa, e era esse." Enfim, durante muitos anos, os pais e os filhos dormiam no mesmo quarto. Só mais tarde, quando Freyre juntou dinheiro para fazer uma reforma, é que outros quartos foram construídos. Então, era um grande esforço para ele parecer um senhor de engenho, se é que ele tinha essa intenção — aliás, acho que não tinha, ao menos inicialmente. Como disse Sonia, sua mãe Magdalena estava sempre atrás do Diário de Pernambuco e da revista O Cruzeiro, periódicos para os quais Freyre contribuía, e também dos seus editores, insistindo que pagassem melhor ao marido.

A casa de Freyre também é interessante de visitar, pois, se não mudou desde a última vez em que estive lá, tem montanhas de papéis até o teto, provavelmente parte grande já impossível de ser lida. Mas ainda há muita coisa a ser achada. Tenho certeza de que lá no meio daquela 
papelada deve estar o manuscrito do Rüdiger Bilden, do livro que jamais foi publicado, que o próprio Freyre confessa ter sido a única pessoa a quem Bilden franqueou a leitura. Há muita coisa a ser descoberta. Nesse quarto grande, onde a família toda dormia, lembro-me de ter visto aberto um ou dois imensos guarda-roupas antigos, com pilhas de papel, do chão ao teto.

0 material que existe para quem quiser mergulhar no material primário continua lá. Jamile [Barbosa] é a responsável por manter tudo aquilo e auxilia muitíssimo os pesquisadores. Na época em que ali estive, o Fernando, filho de Freyre, dirigia a fundação, mas morreu muito cedo. Lembro que estava na Holanda, em Wassenaar, terminando o livro, e havia acabado de the escrever pedindo autorização para utilizar uns textos. Logo depois ele morreu de um aneurisma cerebral, aos 61 anos. A intenção de Jamile é digitalizar o material e catalogá-lo, mas a fundação carece de recursos, ou ao menos essa era a realidade até há pouco tempo. Há necessidade de muita gente especializada para fazer esse trabalho. Imagino que essa dificuldade seja a mesma de muitas outras instituições semelhantes.

É nome de aeroporto, é nome disso e daquilo, mas seu acervo não está digitalizado... [risos].

Exato.

Queria fazer um gancho, porque sua obra continua com o volume seguinte Social theory in the tropics [Gilberto Freyre: Social theory in the tropics]. Três anos depois de Um vitoriano dos trópicos (2005), você publica, em parceria com Peter Burke, um novo livro sobre Gilberto Freyre, dessa vez em inglês, ou seja, deu pano para manga a pesquisa. Mesmo com um livro robusto, premiado e denso sobre Freyre, você continua a tê-lo como um interlocutor, organizando, escrevendo e publicando um novo livro sobre ele. Eu queria ouvi-la sobre esse segundo livro. Mas você tinha ainda alguma coisa para completar...

Falando agora do livro a quatro mãos, ele se diferencia da biografia desenvolvimentista ou genética que publiquei em 2005 porque nele estávamos interessados em escrever um retrato intelectual, um intellectual portrait, que era organizado por temas variados, tentando cobrir as variadas atividades de Freyre como jornalista, como intelectual público — enfim, estávamos tentando estudar Freyre como um todo, "desenhando" o retrato intelectual de um "homem-orquestra" que foi ativo em vários setores da vida brasileira.

Apresentando-o ao público não brasileiro, porque esse era um diferencial.

Sim, um diferencial era apresentar Freyre para o público não brasileiro, que pouco ou nada sabia sobre um de nossos maiores intelectuais do século XX. Mas também achávamos 
que teríamos uma contribuição a dar para o mundo dos estudiosos brasileiros, porque até então, não sei se mudou, não havia um livro que tratasse de Freyre como um todo.

\section{Sim, era Casa-grande \& senzala, "democracia racial", os debates canônicos...}

Nosso objetivo com esse livro, que espero que a gente tenha conseguido, pelo menos em parte, foi oferecer uma imagem de Freyre a mais ampla possível, mas também uma imagem equilibrada, que teria muito a dizer de positivo, de valioso, sobre seus insights, sua originalidade, sua importância para a biografia do país, sem deixar, no entanto, de apontar aquilo que vemos como suas fraquezas. Em outras palavras, a imagem que pensamos ter apresentado aos leitores é a de um Freyre complexo, rico e humano, muito diferente de um modelo de perfeição, que mais parece uma estátua de mármore do que um homem — tal como Freyre criticava as muitas "biografias triunfais" que, como disse, "deixam os grandes homens descansar na sua glória de estátuas", por quererem vê-los "sempre olímpicos e cor-de-rosa".

\section{[0 objetivo era] Não ser um estudo meramente laudatório.}

Exatamente. A ideia tanto minha no "vitoriano dos trópicos" quanto depois em nosso livro a quatro mãos, era apresentar Freyre com toda a sua complexidade, humanidade, contradições, fraquezas e grandezas humanas. Lembrando que uma coisa que sempre me deu força para continuar escrevendo a primeira biografia foram as próprias palavras dele contra a biografia triunfal. Elas me estimulavam a continuar a mergulhar na questão de seu racismo, de sua admiração pelas políticas segregacionistas americanas, na homossexualidade. Também me ajudou a não me intimidar diante da forma pouco honesta com que Freyre procurou denegrir a imagem de um grande amigo e interlocutor, talvez seu maior interlocutor do período formativo, que foi Rüdiger Bilden.

Até o período que segue à publicação de Casa-grande \& senzala, há uma tradição mais conservadora que acusa o livro por falar de sexo. Mas o livro cultiva essa imagem renovadora que vai ser associada a ele tanto do ponto de vista da imagem do Brasil, ao longo dos anos 1930, no período Vargas, quanto de renovação do modo como se escrevia história e se abordava a vida íntima do Brasil. A partir do pós-Segunda Guerra, as próprias posições políticas dele o tornam um intelectual mais visado em virtude de posições pró-salazaristas.

É verdade que o estilo de Freyre atraiu, desde o início, elogios e críticas. Para alguns, seu estilo coloquial, "sem sombra de pedantismo, sem ar doutoral, sem sobrecasaca", era louvável, enquanto, para outros, sua linguagem era indigna. Chegou a ser comparado a um homem que fosse a um jantar formal vestido de jogador de tênis. Mas, deixando de lado a questão 
do estilo freyreano, a crítica, já a partir dos anos 1940, mas crescendo ao longo dos anos, voltou-se mais para a questão política. Aconteceu, então, o que é compreensível, e muitos críticos passaram a olhar Freyre de trás para a frente, como se ele sempre tivesse sido aquela pessoa que tinha certa simpatia pelo regime de Salazar e que apoiara o golpe de 1964. Como decorrência, a tendência de desqualificar e desmerecer o que Freyre fizera de positivo passou a vigorar, deixando-se de lado inclusive seus elogios à lucidez e à dignidade de Luís Carlos Prestes, bem como sua louvação à vitória do Partido Trabalhista britânico em 1945 como tendo um "significado transnacional". Freyre pode ser considerado um contemporâneo, por estar ainda a provocar debate, levantar perguntas, causar reações, muitas delas apaixonadas, mais de oito décadas após sua primeira grande obra ser divulgada no país e, mais tarde, no exterior.

Esse objetivo que vocês tinham no início de dar a conhecer ao público internacional, dez anos depois de publicado - foi publicado primeiramente em 2008 e depois saiu uma versão em português em 2009 —, vocês acham que foi alcançado? Assim como você teve aquela grata surpresa com a resenha do Alberto da Costa e Silva, houve essa recepção ao livro fora do país? Ou mesmo da comunidade brasilianista ou latino-americanista nas universidades?

Não. Acho que ele teve alguma repercussão no mundo dos brasilianistas e latino-americanistas, mas não muito mais ampla do que isso. Nossa maior ambição era levar o Freyre para fora do mundo de brasilianistas e latino-americanistas, pois achávamos que ele tinha coisas importantes a dizer para scholars em geral. A gente esperava que o livro tivesse resenhas publicadas em periódicos de maior circulação, como The Times Literary Supplement, o que não aconteceu. Houve algumas importantes resenhas em periódicos norte-americanos, acho que a maioria, e alguns ingleses, mas o que nos surpreendeu e nos agradou foi uma resenha num importante periódico holandês, Tijdschrift voor Geschiedenis, escrita por um conhecido historiador, que levava Freyre para fora do nicho dos brasilianistas. Acho que isso aconteceu porque chamamos Freyre de "the Brazilian Huizinga [Johan]", que é talvez o maior historiador holandês. Isso chamou a atenção. Mas a gente pode dizer que Freyre e o Brasil - o Brasil de modo geral e Freyre de modo particular - não fazem parte do mapa intelectual e cultural europeu. Quem faz parte do mapa intelectual é Paulo Freire, que é respeitado como um grande educador e mais conhecido como figura internacional, porque diz coisas que interessam a muita gente, que tocam a muitas pessoas de várias origens. 0 Brasil, infelizmente, ainda é relacionado na mente da maior parte das pessoas a carnaval, sexo, violência, belas praias ensolaradas. Agora, nos últimos tempos, à destruição ambiental e ao crescimento do neofascismo - como se prenuncia se Bolsonaro vencer as eleições, como tudo indica.

Como exemplo dessa visão do Brasil como culturalmente pouco rico, lembro quando estávamos no Instituto de Estudos Avançados de Wassenaar, na Holanda, em 2005. Foi lá que 
acabei de escrever o livro sobre Freyre. O Peter, como fellow do Instituto e também da Royal Library em Haia, tinha como obrigação dar um seminário sobre um tópico de sua escolha. Como já estávamos pensando em escrever o livro a quatro mãos, e talvez por querer testar o tema diante de uma plateia estrangeira, ele escolheu falar sobre Freyre. Ficou óbvio que falar sobre um brasileiro desconhecido frustrou as expectativas dos seus colegas fellows do instituto. Lembro-me bem dos comentários surpresos de vários deles, que esperavam ouvir de Peter Burke, um conhecido historiador cultural, algo sobre o Renascimento europeu, ou algum tema considerado elevado na chamada hierarquia dos assuntos. Lembro que um dos fellows chegou para mim e falou mais ou menos o seguinte: "He is going to speak about a Brazilian topic? Gilberto Freyre, who is that? I was expecting a talk about, you know, Europe... Has he given up Europe?"

\section{Uma coisa exótica, bizarra...}

Imagino que o tema escolhido pelo Peter tenha sido visto pela grande maioria dos fellows mais ou menos desse modo: "Como assim? 0 grande historiador da cultura europeia está falando de uma pessoa que ninguém conhece, ainda mais um latino-americano, um brasileiro?" Não acredito que houvesse a intenção direta de menosprezar Freyre, mas era óbvio o choque, o estranhamento, e a consciência de que era um assunto irrelevante ou "menor". Um dos objetivos de nosso livro era mostrar a relevância de um estudo de um pensador que não era europeu para os europeus ou para os não brasilianistas ou latino-americanistas que já o conheciam. Mas, infelizmente, o problema não é só o Freyre; é o Brasil de modo geral, que não faz parte do mapa intelectual.

\section{Isso porque não existe uma política científica, porque não houve essa internacionali- zação para a aplicação em língua inglesa?}

Exatamente. Traduções do português são bem raras ainda e dificultam muito a divulgação de ideias produzidas no nosso contexto linguístico. 0 livro de entrevistas, As muitas faces da história, que é meu livro de maior sucesso, foi traduzido para cinco línguas, mas só depois que saiu em inglês. Inclusive a tradução para o espanhol foi feita com base no inglês, o que vejo como um absurdo, pois seria muito melhor o texto em espanhol ser traduzido diretamente do português. Há o problema da língua, que limita o alcance de certas ideias. Como disse Fernand Braudel a respeito de um brilhante mas pouco conhecido historiador polonês, diferentemente dele, que tinha um alto-falante francês a Ihe garantir maior audiência, as inovações de Witold Kula, por mais importantes que fossem, estavam mais ou menos fadadas a ficar confinadas ao seu contexto linguístico. Mas, além do problema linguístico, há também um problema de perspectiva, já que um "centro" cultural tende a mostrar pouco interesse pelas chamadas "periferias". Nossos grandes intelectuais e autores são desconhecidos fora do Brasil, com poucas 
exceções, como Clarice Lispector. Ela é muito valorizada aqui, e as pessoas muitas vezes nem sabem que ela é brasileira. Mesmo Machado de Assis não é conhecido como deveria.

É uma dupla barreira: a da língua portuguesa e a do posicionamento dos intelectuais brasileiros nesse debate.

É triste.

É até um diferencial do próprio Freyre, por ele romper com a tradição francófona dos brasileiros, muito voltada para a França. Ele tem uma trajetória que o diferencia e que também contribui para que trouxesse novas ideias ou uma maior perspectiva sobre 0 Brasil. Tem a ver com essa relação com o mundo anglo-saxão, com universidades de ponta, Columbia, Oxford...

Ele tinha muito orgulho de ter estado em Columbia, e um orgulho imenso, talvez até maior, de ter estado em Oxford. Ali Freyre passou pouco tempo, mas foi marcante pela sua confessa anglofilia, já tão presente desde muito jovem, por ter tido ocasião de se saciar com tudo o que ali viu e viveu, bem como pela experiência que teve com Linwood Sleigh.

A gente poderia passar para, vamos dizer, essa sua outra obsessão, ou esse outro traço detetivesco das suas pesquisas, que foi o interesse em torno desse autor alemão, Rüdiger Bilden. Não se pode dizer que é um esgalho, porque ele quase adquiriu o mesmo volume, a mesma proporção em termos, pelo menos em termos quantitativos de pesquisa, de resultados com esse livro 0 triunfo do fracasso $[0$ triunfo do fracasso: Rüdiger Bilden, o amigo esquecido de Gilberto Freyre], de 2012. Se você puder comentar um pouco...

Como admito no começo do livro, ele é fruto de uma obsessão. Descobri o Rüdiger Bilden quando estava escrevendo sobre Freyre, porque ele aparecia nos documentos da Columbia University como um dos mais brilhantes estudantes daqueles anos, alguém muito promissor, do qual se esperava muito. Acompanhando a trajetória de Freyre, percebe-se também quanto ele inicialmente admirava Rüdiger Bilden, quanto devia a Rüdiger Bilden. Até em Casa-grande \& senzala ele confessa isso. Acompanhando a trajetória de Freyre, vê-se como, aos poucos, Bilden vai perdendo importância e chega um momento, não me lembro exatamente o ano, em que Freyre se refere ao velho amigo de forma depreciativa, dizendo que ele fracassara em escrever sobre a escravidão brasileira — um "assunto meu", diz Freyre — por "excesso de bebida". Em toda a minha vasta pesquisa, jamais apareceu qualquer referência a um problema desse tipo na vida de Bilden. Sua mulher, sim, bebia muito, e foi esse o motivo maior do divórcio do casal. 


\section{Que era norte-americana.}

É, e da qual ele se separou muito cedo. Quando resolvi escrever o livro sobre Bilden, é porque eu achava que ninguém pode desaparecer por completo. "Alguma coisa, algum traço ele deve ter deixado, então vamos lá, vamos ver o que é possível." Já no livro sobre Gilberto Freyre, eu dedicara umas trinta páginas sobre o Bilden. Ali anuncio minha intenção de escrever um livro sobre ele, mas, na verdade, eu temia que pudesse achar material só para escrever um artigo mais ou menos substancioso. Mas não, achei o suficiente para escrever um livro, e me sinto privilegiada de ter tido a sorte - porque há numa pesquisa, como em tudo o mais, um elemento de sorte — de descobrir muita coisa sobre o Bilden, inclusive sobre sua família. Atribuir isso a um mérito puramente intelectual, à mera capacidade, não seria honesto. Enfim, pensei que não fosse conseguir descobrir muito sobre o lado pessoal de sua vida. Minha grande conquista, da qual muito me orgulho, foi ter descoberto a existência e conhecer pessoalmente o único membro sobrevivente da família de Bilden, a sobrinha Helga, que jamais o conheceu. Também me acho muito privilegiada de ter podido entrar em contato com um poeta, colega de Bilden e que já estava com 94 anos na época em que o conheci. Ele deu um belo depoimento sobre Bilden.

\section{Na Alemanha?}

Não, nos Estados Unidos. Samuel W. Allen, é seu nome. Esses dois encontros foram de grande valor para mim. Lembro que, no caso da sobrinha, eu não sabia nem como chegar à família Bilden nem se existiria alguém, porque do lado dos Estados Unidos eu sabia que ele não deixara descendentes. Fora casado com Jane, divorciara-se, não teve filho e não se casou novamente. Do lado alemão, eu não sabia por onde começar a investigar, já que nada sabia sobre sua família, a não ser que tinha um irmão. Foi no Instituo de Estudos Avançados de Wassenaar, na Holanda, que encontrei um historiador alemão que me deu uma informação preciosa.

Eu sabia que ele havia nascido na cidadezinha de Eschweiler e estava pensando em escrever para os Bilden que porventura ainda vivessem lá. Ele falou: "É uma ótima ideia." Eu nem sabia que eu podia ter acesso à lista telefônica com o endereço de todos os Bilden que existem na Alemanha; foi por intermédio desse historiador que eu soube. Ele me ajudou a passar para um alemão perfeito a carta que redigi e que mandei para todos os Bilden que encontrei na lista telefônica, espalhados por todo o país. Escrevi uma carta cuidadosa, dando dados que poderiam ajudar os destinatários a reconhecer se eram ou não parentes do "meu" Rüdiger Bilden. E lá se foram as cartas, que continham meu e-mail e o endereço postal, porque pensei que, dependendo da idade das pessoas, elas não usariam e-mail. Lembro que esse jovem historiador alemão me disse: "Vou ajudá-la, mas, se conheço meus compatriotas, você não vai ter resposta." Ledo engano. Muita gente, quase todos, me responderam. 


\section{Por e-mail ou por cartas?}

Cartas, mas muitos por e-mail também. Isso foi em 2006. Muitos lamentavam não serem parentes do "meu" Bilden, mas se mostravam interessados pela pesquisa. Muito interessante e até comovente foi essa recepção que tive entre os Bilden alemães. Mas nada chegava de positivo, até o dia em que abri meu e-mail e, em alemão, havia uma mensagem que começava assim: "Na verdade, sou sobrinha, filha do irmão dele que esteve no Brasil...". Eu nada sabia sobre a família de Rüdiger, a não ser, por cartas, que ele tinha um irmão que fora tentar trabalho no Brasil, em 1926, com a ajuda de Rüdiger. Eu tinha o nome desse irmão, a data em que ele fora para o Brasil, o navio em que viajara, e isso tudo coloquei na carta. Assim, foi relativamente fácil para Helga confirmar que era seu pai.

Após isso, a história de Bilden ganhou outras cores, outra vida. Cheguei a me encontrar com a sobrinha em Eschweiller, conheci a cidade, onde até o prefeito me recebeu, acredita? Houve uma pequena matéria no jornal sobre minha pesquisa e minha visita à cidade, com foto e tudo. Na época de Bilden, Eschweiller ficava numa região rica; hoje em dia, não mais, é pobre. A prefeitura e a sociedade histórica tentaram traduzir meu livro sobre Bilden, mas não conseguiram, por falta de verba. Mas, nesse dia memorável, estive mais de uma hora conversando com o prefeito e com representantes da sociedade histórica de Eschweiller. Foram eles que me colocaram em contato com uma pessoa, bem velhinha, que havia conhecido os Bilden e que me passou dados sobre a família, a casa — porque ela morara na mesma rua, quase em frente a eles. Então, tive esses privilégios de descobrir coisas que jamais poderia esperar e que me deram um grande incentivo para perseverar nessa busca pela história do promissor aluno de Columbia.

\section{E foi se transformando nesse volume de mais de quatrocentas páginas...}

Descobri atividades de Bilden não só como intelectual e professor universitário, com empregos esporádicos, mas também como um ativista, em que teve um papel muito importante. Pode-se dizer que Bilden fazia parte do pequeno "grupo Boas", que, ao lado do grande mestre, estava lutando contra o preconceito racial, contra o racismo científico, numa luta que, por algum tempo, parecia inglória. Ele foi participante disso com as aulas que dava em centros culturais - até em igrejas de Harlem, o bairro negro de Nova York. O objetivo maior de Bilden, que fica claro nas aulas, era estimular nos negros a autoestima. Como? Encorajando-os a se interessar pela cultura negra e africana, delas se orgulhando. Foi assim que Bilden, talvez 0 interlocutor mais importante na formação de Gilberto Freyre, adquiriu outra dimensão como indivíduo que teve um papel importante nos preâmbulos do movimento dos direitos civis norte-americanos. 


\section{Mas imagino que isso não seja reconhecido lá.}

Não, nem pessoas estudiosas de Franz Boas conheciam o nome de Bilden. Mas tenho os documentos que provam que ele era tão íntimo de seu mestre que até chegou a morar em sua casa. Porque, na verdade, qualquer estudo é sempre seletivo, e muitas vezes não é uma seleção consciente dos buracos que são deixados pelo caminho. 0 grande estudioso de Franz Boas, George Stocking, com o qual entrei em contato, me disse: "Esse nome, infelizmente, não conheço, mas pode haver muita gente que não conheço e que fez parte do hall de amigos, conhecidos e alunos de Franz Boas." Sempre há buracos em qualquer trabalho histórico, em qualquer biografia; nunca se conhece tudo. Ernst Gombrich equipara a história individual ou coletiva a um queijo suíço, cheio de buracos irrecuperáveis, que a mais cuidadosa pesquisa feita pelo mais talentoso historiador ou biógrafo é incapaz de preencher totalmente.

\section{A Biblioteca Nacional tinha uns programas de tradução, uns editais de tradução...}

Eu gostaria, obviamente, que a biografia de Bilden tivesse sido traduzida para o inglês e para o alemão e que houvesse interesse, mas não aconteceu. Houve um especial empenho para que ocorresse a tradução para o alemão, tanto da parte de Helga Bilden, que é professora universitária, quanto da cidade de Eschweiler, e até de um estudante de doutorado alemão. 0 próprio editor da Unesp, Jésio Gutierrez, muito se empenhou, mas ele bem reconhece que é muito difícil conseguir fazer um livro em português ser traduzido. Há uns dois anos, fui convidada para escrever um capítulo num livro sobre Franz Boas, a ser publicado pela Yale University Press, que trata da repercussão de suas ideias pelo mundo, assim como das ideias que ele absorveu de fora. Chama-se Indigenous visions: Rediscovering the World of Franz Boas.

Fui convidada pelo editor Isaiah Lorado Wilner a escrever sobre Freyre, por ele ser conhecido como discípulo de Boas. Expliquei a ele que eu não escreveria somente sobre Boas e Freyre, mas sobre Boas, Freyre e Bilden. Ele se entusiasmou, aprovou minha sugestão, e foi essa a oportunidade que tive para escrever um capítulo sobre Freyre e Bilden, ao qual dei o título de "A two-headed thinker: Rüdiger Bilden, Gilberto Freyre and the reinvention of Brazilian identity". O livro saiu há pouco tempo, e o que me agrada é que esse capítulo faz parte de um livro que não é somente dirigido aos estudiosos do Brasil ou da América Latina, mas a um público mais amplo, interessado no mundo de Franz Boas.

\section{Que seria uma síntese do seu livro...}

O capítulo é, em parte, uma síntese do livro, mas dando muito maior ênfase às ideias de Boas que Freyre e Bilden exploram. Saiu agora em 2018. Isso me alegrou, me deu um pouco de esperança de que Bilden vá ser mais conhecido. Tentei ser equilibrada, imparcial, mostran- 
do o lado de Freyre, o lado de Bilden, e o trabalho em conjunto que eles desenvolveram. Na verdade, mostrando-os, em certo sentido, como colaboradores de um belo projeto.

\section{Companheiros de geração que tiveram as mesmas questões e inquietações...}

E que se auxiliaram mutuamente, porque Freyre teve também importância para que surgisse o interesse de Bilden pelo Brasil. Mas procurei deixar claro quanto, muito antes de Freyre publicar Casa-Grande, o trabalho que Bilden estava desenvolvendo fora enaltecido por intelectuais brasileiros da envergadura de Oliveira Lima, Roquette-Pinto e Vicente Licínio Cardoso como um estudo pioneiro do legado sombrio da escravidão para o Brasil moderno.

Até coloquei no roteiro, não sei se você chegou a conhecer esse romance do Bernardo Carvalho, um autor da literatura brasileira contemporânea, prêmio Jabuti com Nove noites. É um misto de uma ficção com passagens documentais. Lembrou-me da sua pesquisa sobre Bilden pelo traço detetivesco. Na origem do romance, Bernardo Carvalho leu um artigo da Marisa Corrêa, especialista em história da antropologia brasileira, que saiu na Folha de S.Paulo, falando desse antropólogo norte-americano que vem para o Brasil e comete suicídio quando estava em campo, em 1939, e fica completamente tomado pelo episódio verídico.

\section{Ele não é o antropólogo que teve ligação com o Museu Nacional? Eu já havia ouvido falar nele.}

Isso, Buell Quain. Ele [Bernardo Carvalho] vai e escreve cartas para os Quain que havia nos Estados Unidos e o livro mescla ficcional com o que ele pôde apurar dessa história.

\section{E por que ele cometeu suicídio?}

0 livro tenta inferir por que poderia ter acontecido. Ele vai rastreando aspectos da história de vida dele, afinal é muito difícil dizer o que o levou a cometer suicídio, mas há um relato muito impressionante. Maria Lúcia, acho que a gente pode ir caminhando para o fim da entrevista. Assim como você mencionou a resenha do Alberto da Costa e Silva, lembrei que comentou, antes de a gente começar a gravar, a leitura do professor Afrânio Garcia Jr. de Triunfo do fracasso. Eu ia lhe perguntar sobre a recepção do livro.

O Afrânio me escreveu uma mensagem generosa e muito comovente ao receber meu livro, confessando-me que eu chegara num momento difícil, em que ele estava enfrentando uma doença séria, da qual, felizmente, sei que se recuperou. A leitura do livro, disse ele, estava lhe fazendo um "bem imenso" e lhe reforçava a vontade de perdurar, pois "há tanto a fazer" e aprender. 
Sua ideia, naquele momento, era escrever uma resenha de $O$ triunfo do fracasso assim que estivesse melhor, mas que acabou nunca sendo finalizada. Ele já escrevera uma bela resenha de meu Vitoriano dos trópicos que fora publicada na revista dos Annales. No entanto, seus ricos comentários sobre a biografia intelectual de Bilden já valeram para mim como se fossem uma resenha, que me deixou imensamente feliz. 0 fato de o livro tratar de "circulação internacional de ideias" e de ser uma "biografia heurística", como disse, não centrada em indivíduos "geniais", parecia-lhe especialmente valiosa para apreciar a contribuição de doutorandos estrangeiros para o perfil das instituições nacionais e internacionais. A relação entre os debates teóricos e a militância antirracismo também o atraiu, inclusive porque, como diz, pouco ou nada se sabe hoje sobre o fato de, no bairro negro de Harlem, nos anos 1920, imagens do Brasil terem reforçado o ânimo de enfrentar a segregação.

\section{E o livro chegou a ter recepção no Brasil? Dentro da história das Ciências Sociais no Brasil, é uma página inédita, é um autor que você traz que tratou de relações raciais, algo tão caro à realidade brasileira, e que esteve no Brasil.}

Primeiramente, antes do lançamento Brasil, lancei o livro na Frankfurt Fair, que atraiu um público interessado no Brasil e no papel importante que um alemão teve na luta contra a segregação racial norte-americana ao longo de décadas. É difícil, no entanto, medir se o livro teve qualquer impacto mais duradouro. Tive também boas resenhas, que ajudaram muito na divulgação da obra. Alguns convites surgiram a partir daí, para Rio de Janeiro, São Paulo e Recife. No Rio, estive no Colégio Brasileiro de Altos Estudos da UFRJ, a convite do professor José Sergio Leite Lopes, onde houve uma discussão muito boa com a presença do Peter Fry e outros intelectuais de igual calibre. Em Recife, onde estive após o lançamento em São Paulo, e onde também foi feito um pequeno lançamento no Expoidea de 2013, senti um ligeiro mal-estar. Fui entrevistada várias vezes naquela ocasião e tive a impressão de que, para muitos, era incompreensível que após uma biografia de Freyre em que este ganhava em humanidade, a mesma autora escrevesse uma biografia em que um lado mais sombrio de Freyre fosse ressaltado. 0 que foi um tanto frustrante foi perceber que, apesar de o livro sobre Bilden ter mais de quatrocentas páginas, das quais somente trinta foram dedicadas a Freyre, ou melhor, ao relacionamento entre os dois amigos — "Freyre e Bilden: um sucesso a partilhar?" —, muitos leitores parecem ter deixado Bilden totalmente de lado e se voltado unicamente para essas páginas sobre Freyre que estão no fim, no epílogo.

\section{Porque é a referência mais familiar.}

Deve ser, mas é uma pena, porque acho que a trajetória de Bilden é muito bonita, tem muito a ensinar. Enfim, ele é uma figura generosa e cativante, que, independentemente de Freyre, merece ser estudada por si própria. Por meio de sua história, que não deixa de ter lados 
comoventes, podemos conhecer aspectos das relações raciais norte-americanas, da história das relações dos Estados Unidos com a América Latina, do papel que o Brasil ocupava no imaginário norte-americano e muito mais.

Quando eu estava em Recife, no entanto, soube que havia um historiador, cujo nome não me recordo, que estava a dizer que 0 triunfo do fracasso era "um livro esquizofrênico", dando a entender que contrariava o que fora dito sobre Freyre no Vitoriano dos trópicos ao enaltecer o "inimigo" do mestre de Apipucos. Soube que o livro sobre Bilden também gerou um mal-estar na família de Freyre, de quem me tornei próxima ao longo dos anos, mas não chegou a abalar nosso relacionamento. Penso que grande parte desse mal-estar seria facilmente sanado se as pessoas conhecessem a trajetória de Bilden e se, em vez de pularem grande parte do livro, lessem o que minha pesquisa mostrou sobre seu caráter, sua generosidade, seus esforços, suas ambições, suas realizações, que, apesar de periféricas, foram importantes e fizeram diferença no mundo. Poderiam reconhecer que minha intenção não fora denegrir Freyre, mas dar a Bilden o que lhe é devido e, ao mesmo tempo, ampliar o quadro em que Freyre se insere, contribuindo para uma compreensão mais ampla de sua trajetória. Apontando as ideias de Bilden que Freyre retoma e amplia, não se pretende negar sua originalidade, e sim tentar definir essa originalidade com maior precisão. Afinal, muitas, se não todas, as ideias novas, quando analisadas detidamente, terminam por se mostrar adaptações criativas de outras anteriores.

Não existe um gênio no pedestal, isolado, que está lá pensando sozinho ideias inovadoras. Houve uma geração, passaram pela mesma instituição, pelos mesmos professores...

Exato. As reações negativas que o livro sobre Bilden teve foram, na verdade, bem poucas, e entendo que fazem parte da vida acadêmica. Só a acusação de ser "um livro esquizofrênico" me chocou mais, e ainda me lembro de vez em quando.

A gente pode passar para comentar sua publicação mais recente. Há certa novidade, porque é um livro de encomenda da editora Contexto, também escrito a quatro mãos com o Peter Burke, Os ingleses, de 2016. Se você puder comentar um pouco, voltar ao tema das relações identitárias, da relação Brasil-Inglaterra, da discussão sobre o caráter nacional e da identidade nacional, como você diz sempre, que é precária, provisória e transitória... Desse outro ângulo, pensando as especificidades dos ingleses, essa discussão interessante da identidade nacional, mas nessa configuração que vivemos hoje, do século XXI, do multiculturalismo, da globalização, uma discussão não está mais pensada nos termos dos anos 1930. Se você puder falar um pouco desse livro... De alguma forma, você comentou que o próprio Freyre lhe chega por meio do livro Os ingleses no Brasil. São dois livros; o outro é chamado apenas Os ingleses. Você traz 


\section{esse tema que está relacionado também ao interesse pelo Freyre. Você diz também que é um livro de encomenda, que relutou um pouco em fazer no início...}

Relutei, é verdade. Eu não queria escrever um livro sobre caráter nacional porque não acredito num caráter nacional. A editora me mandou vários dos outros livros dessa coleção Povos, e achei que não tinha conhecimento suficiente para fazer um livro interessante que me agradasse. Diante da insistência deles, pensei que poderia escrever talvez esse livro em diálogo, pois me pareceu claro que seria um livro mais interessante, para mim e para os leitores, se a gente pudesse fazer um livro a quatro mãos, fruto de um diálogo entre um britânico e uma brasileira. Convenci Peter a me acompanhar nessa empreitada, muito diferente de qualquer coisa que tanto ele quanto eu havíamos feito antes, e confesso que foi uma experiência mais interessante do que eu imaginara. Aprendemos muito, rimos muito, trabalhamos muito. Eu, especialmente, fiz uma imersão em jornais do passado e atuais para tratar dos vários temas que decidimos abordar. Foi um livro muito diferente para nós, mais próximo do jornalismo do que um trabalho de pesquisa profunda, apesar de termos listado livros importantes para aqueles leitores que quisessem se aprofundar nos diferentes tópicos. Nosso objetivo era falar da cultura no sentido amplo, no sentido de Franz Boas, buscando os valores da cultura inglesa como se expressam nas suas práticas. É um livro que tem de tudo — de tudo é um exagero, porque não se pretende exaustivo - , mas é amplo o suficiente para ir de habeas corpus, monarquia e BBC até fish ' $n$ ' chips, chá da tarde e cerveja.

\section{Até porque talvez seja congruente com o perfil do livro que se esperava, para um pú- blico mais amplo, não para o público acadêmico. Há essa abrangência de elementos do cotidiano, dos costumes.}

Na verdade, cheguei a pensar enquanto eu estava decidindo aceitar o convite: "O livro que quero escrever é o que eu gostaria de poder ter lido antes de vir para a Inglaterra." O que está por trás de algumas coisas interessantes, até de coisas banais, como fish ' $n$ ' chips; o que está por trás desse louvor que grande parte dos britânicos tem pelo NHS, National Health Service, porque aqui, como descobri, poucos são os que se dispõem a ter um seguro de saúde particular. Entre nossos amigos, só os estrangeiros. A maioria, no entanto, tende a considerar o NHS algo sagrado, representativo da identidade da cultura inglesa, a ser defendido bravamente. Haja vista a importância que teve o NHS na abertura dos Jogos Olímpicos em 2012. Foi uma homenagem lindíssima, o ponto alto da abertura. Não sei se você se lembra, mas foi feita por um grande diretor de cinema, Danny Boyle. Nossa preocupação era explorar o que está por trás disso, por exemplo, dessa veneração pelo serviço de saúde pública e universal. E da BBC, que alguns criticam, mas que a maioria se orgulha? 0 que faz a BBC ser o que é? Enfim, nossa ideia - e minha, especialmente - era escrever um livro que eu gostaria de ter lido. Para escrever esse livro, aprendi muito, e até o Peter descobriu coisas que não conhecia. Mas qual era sua pergunta mesmo? 
A discussão da identidade nacional vista do século XXI. No seu caso, voltar a esse debate que fez em torno da obra de Freyre. Falando aqui da identidade, nas suas palavras, sempre precária e transitória, como ela se situa no século XXI?

É uma coisa fluida, sem dúvida, mas há alguns pilares que sustentam essa fluidez. Por exemplo, o amor que a cultura inglesa tem pela liberdade é uma coisa impressionante e persistente. Mas esse valor não é isolado de outros que com ele contrastam. É verdade que o Brexit está causando um verdadeiro terremoto político, mas pode-se dizer que essa decisão tanto quebra quanto segue tradições inglesas. De um lado, com seu desejo de exercer controle da imigração, o Brexit representa uma quebra da tradição de não só aceitar imigrantes e refugiados, como de Ihes dar as boas-vindas; de outro, representa a continuidade da tradição de se rebelar contra tudo o que limita sua liberdade, como são vistos os burocratas de Bruxelas impondo suas leis. Assim, o Brexit demonstra o que um jornalista holandês do século XVIII já chamava de "amor desmedido pela liberdade" tão típico dos ingleses. "Tudo que incomoda, tudo que constrange, Ihes é insuportável." Pode-se pensar, pois, que Brexit foi um erro terrível, mas não podemos descrevê-lo como completamente un-english. Um exemplo dessa obsessão pela liberdade é o fato de não termos aqui qualquer carteira de identidade. Se você me manda alguma coisa que vai para o correio, como vou buscar? Como mostro que sou quem sou? Se eu não tiver passaporte — e ninguém é obrigado a ter passaporte — não posso levar passaporte para me identificar. E se eu não for motorista e, portanto, não tiver uma carteira de habilitação que poderia me identificar? A maior parte das pessoas leva a carteira de motorista, que tem a fotografia e o endereço, mas, novamente, não é obrigatório ter uma carteira de motorista. Então isso é um problema. Ou seja, a inexistência de uma carteira de identidade atrapalha até a vida do dia a dia, mas pelo menos até agora essa solução não foi aceita pelos britânicos, porque significa uma intromissão inaceitável na sua privacidade e sacrossanta liberdade.

Mencionei que o desafio era inverso, porque, ao escrever o Social Theory in the Tropics, você queria explicar como o Brasil percebeu sua identidade nacional para os ingleses, e, nesse caso, seria explicar para os brasileiros como os ingleses percebem a própria cultura. Foi quase um sinal trocado com esse livro de encomenda que você disse que aprendeu muito...

Aprendi, porque muito sobre o que escrevemos me era pouco conhecido. Até o Peter aprendeu muito sobre o que estava por trás de certos aspectos de sua cultura. Foi um livro interessante e que, dentro da série Povos, diz a editora, que está muito bem, vende muito bem. Na verdade, seria importante atualizarmos o livro, porque o Brexit não havia acontecido quando a gente acabou de escrever. E tanta coisa aconteceu desde então! 


\section{Maria Lúcia, para terminar, uma curiosidade: você tem algum projeto atual, algum desdobramento dos projetos anteriores, o que você está fazendo no momento?}

Eu e o Peter estamos planejando um terceiro livro a quatro mãos que ainda está em estágio de mapeamento, até porque o Peter ainda está terminando o livro dele sobre o papel dos polímatas na história cultural. Trata-se de um tema sobre o qual eu já tinha muito interesse. Basicamente, tratará de viagem e conhecimento, ou seja, estamos interessados, de um lado, em que tipo de conhecimento as pessoas precisam para viajar — como mapas, guias etc. - ; e, de outro, em viagem como um meio de adquirir conhecimento, como as expedições científicas que buscavam ampliar o conhecimento explorando várias partes do mundo, bem como viagem como um meio de obter autoconhecimento e de ver o próprio país com novos olhos, ou seja, ver o que de perto não se vê com clareza. Ainda está muito cru. Posso falar que um dos capítulos desse livro ainda em planejamento vai cobrir, talvez, mil anos. Será sobre guias de viagem, indo desde os guias medievais, que eram destinados aos peregrinos, até os rough guides de hoje, que são guias para os jovens que querem viajar pelo mundo com pouco dinheiro e que não se importam com desconforto. Como nos outros livros, a gente pretende escrever esse a quatro mãos mesmo. Seria mais fácil a gente dividir: "Você escreve esse capítulo e eu escrevo aquele outro." Mas preferimos seguir fazendo o que temos feito: um escreve, o outro revê, mexe e remexe, manda de volta, e fica nesse vai e vem até acharmos que o texto atinge um estado que agrada a nós dois.

\section{0 próprio Freyre tinha o roteiro sentimental de Recife [Guia prático, histórico e sentimental da cidade do Recife, 1942], enquanto Manuel Bandeira escreveu sobre a viagem a Ouro Preto.}

Acho que foi em 2013 que fui convidada para o aniversário da cidade de Recife, e nessa ocasião trabalhei do zero - porque eu não havia me dedicado a ele antes — sobre esse guia da cidade de Recife. Muitíssimo interessante e sui generis, escrito por um apaixonado pela cidade.

\section{E você vai poder aproveitar para esse livro de viagens.}

Sim, espero aproveitar bastante, pois é um belo livro e bastante inovador no âmbito de guias. Vamos ver como vai ser esse livro. 0 difícil é acompanhar o Peter na sua produção, porque ele é muito rápido.

\section{Mas isso é uma virtude...}

É uma virtude, mas, apesar de ser um incentivo à produção intelectual, é difícil seguir o mesmo ritmo. Prefiro um passo mais espaçado. 


\section{REFFERÊNCIAS}

Pallares-Burke, Maria Lúcia Garcia. Gilberto Freyre - Um Vitoriano dos Trópicos (2005), São Paulo : Editora Unesp.

Pallares-Burke, Maria Lúcia Garcia. 0 triunfo do fracasso: Rüdiger Bilden, o amigo esquecido de Gilberto Freyre (2012), Editora Unesp.

\section{Errata}

DOI: http://dx.doi.org/10.1590/s2178-149420190003000012

Para o texto: Entrevista com Maria Lúcia Garcia Pallares-Burke

Citação:

HOLLANDA, Bernardo Buarque de. Entrevista com Maria Lúcia Garcia Pallares-Burke. Estud.hist. (Rio J.), Rio de Janeiro , v. 32, n. 68, p. 765-811, dez. 2019. Disponível em <http://www. scielo.br/scielo.php? script=sci_arttext\&pid=S0103=21862019000300765-\&lng=pt\&nrm-iso>. acessos em 25 mar. 2020. Epub 13-Dez-2019. https://doi.org/10.1590/s2178149420190003000011.

Na página 768 do arquivo em PDF, $4^{\circ}$ e $5^{\circ}$ parágrafos

\section{ONDE SE LÊ :}

E qual era a profissão de seu pai? Meu pai, apesar de gostar muito de estudar, não fez universidade. Teve uma vida familiar muito complicada. Perdeu a mãe com oito anos, teve de se mudar para a capital com o pai, para longe da fazenda, perto de Durazno, que adorava, e ele logo se casou com Carlota, uma beldade de Montevidéu. Com dezesseis ou dezoito anos, fugiu de casa e veio parar no Brasil.

\section{LEIA-SE:}

E qual era a profissão de seu pai? Meu pai, apesar de gostar muito de estudar, não fez universidade. Teve uma vida familiar muito complicada. Perdeu a mãe com oito anos e teve de se mudar para a capital com o pai, para longe da fazenda perto de Durazno, que adorava, quando Don Esteban se casou com Carlota, uma beldade de Montevideo. Com dezesseis ou dezoito anos, fugiu de casa e veio parar no Brasil. 